\title{
HOW DOES THE PROFESSIONAL IDENTITY OF TEACHERS FROM INDIA CHANGE WHEN THEY WORK AS EARLY CHILDHOOD EDUCATORS IN ONTARIO?
}

by

Preeti Alwani, BA, Wilfrid Laurier University, 2009

\author{
A Major Research Paper \\ Presented to Ryerson University \\ in partial fulfillment of the requirements for the degree of \\ Master of Arts \\ in the Program of \\ Immigration and Settlement Studies
}

Toronto, Ontario, Canada, 2014

(C)Preeti Alwani 2014 


\section{AUTHOR'S DECLARATION FOR ELECTRONIC SUBMISSION OF A MAJOR RESEARCH PAPER \\ (MRP)}

I hereby declare that I am the sole author of this Major Research Paper. This is a true copy of the MRP, including any required final revisions, as accepted by my examiners.

I authorize Ryerson University to lend this MRP to other institutions or individuals for the purpose of scholarly research

I further authorize Ryerson University to reproduce this MRP by photocopying or by other means, in total or in part, at the request of other institutions or individuals for the purpose of scholarly research.

I understand that my MRP may be made electronically available to the public.

$<$ Preeti Alwani $>$ 


\title{
HOW DOES THE PROFESSIONAL IDENTITY OF TEACHERS FROM INDIA CHANGE WHEN THEY WORK AS EARLY CHILDHOOD EDUCATORS IN ONTARIO?
}

\author{
Preeti Alwani \\ Master of Arts 2014 \\ Immigration and Settlement Studies \\ Ryerson University
}

\begin{abstract}
Many Early Childhood Educators (ECE) in Toronto are foreign-educated teachers. They take up this profession because they cannot enter the teaching profession. Training as ECEs takes a shorter time, has lower entry requirements, and is more affordable. The case studies undertaken for this project are based on qualitative data collected by interviewing and observing two former teachers from India, now working as ECEs in a for-profit daycare. The data shows that because of low compensation rates, poorer working conditions, and lack of appreciation, community and respect, especially compared to what they received in India, these teachers report a downward spiral in their professional identity. Their daily routines and practices follow the norms in childcare centers, but they feel as though their employers and parents do not value them. As a result, these ECEs struggling to suppress their dominant teacher identity, think of themselves simply as 'babysitters' and do not value the work they do.
\end{abstract}

Keywords: professional identity, immigrant women, India, teachers, ECE 


\section{Acknowledgements}

I would like to thank my parents and my two siblings for always being my backbone and reminding me how blessed I am for having been given this opportunity. I would also like to thank my extended family and friends.

I would like to thank my supervisor Mehrunnisa Ali without whose guidance, patience and support I would not here. As well, I would like to acknowledge my professors from other classes and my fellow graduate students who helped me through this process. 


\section{Table of Contents}

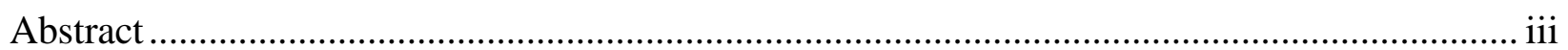

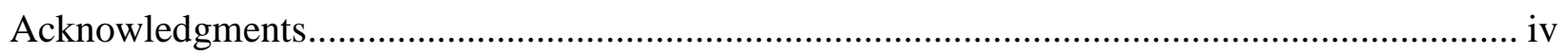

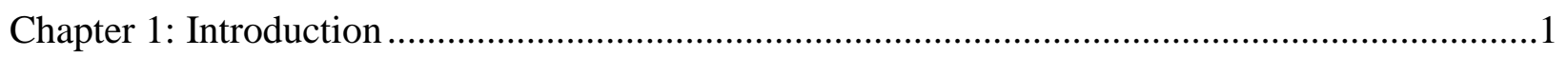

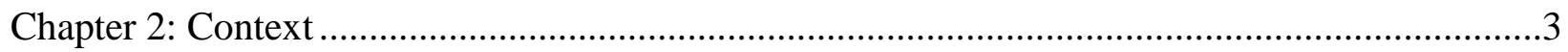

Chapter 3: Theoretical Framework .......................................................................................10

Chapter 4: Literature Review..........................................................................................12

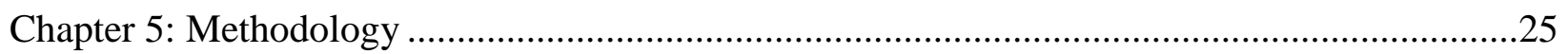

Chapter 6: Participant Profiles ........................................................................................................35

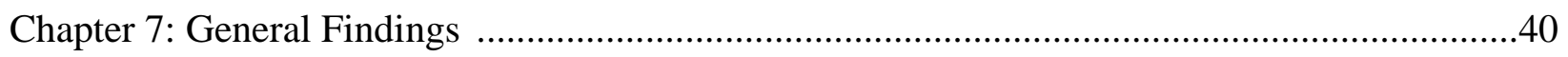

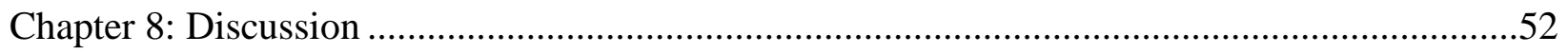

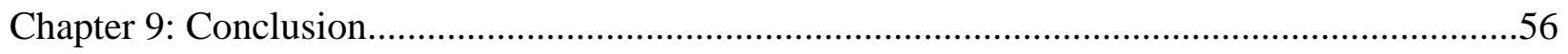

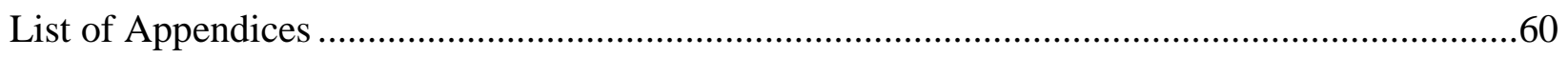

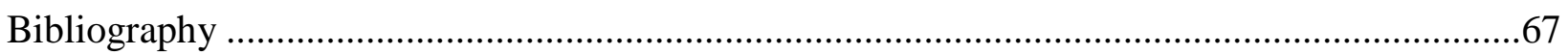




\section{Introduction}

Immigrants who are entering Canada today are more highly educated than ever before (Iredale, 2004; Bauder 2003; Walsh, 2007 et al.). The establishment of the points system in 1967 enabled immigrants to migrate to Canada regardless of their country of origin, race, gender and profession and trade (Kelley and Trebilcock, 2000). Thus, immigrants were able to enter the country based on their education level, proficiency in the official languages of Canada and other factors that were considered important for adaptability. In 2008, close to $45 \%$ of newcomers held a university degree, more than double the proportion 14 years earlier (Houle and Yssaad 2010). Yet, researchers have found that immigrants' credentials and work experience obtained outside Canada are valued less than credentials and experience of comparable Canadian-born individuals (Schmidt 2010; Schmidt et al., 2010; Houle and Yssaad, 2010).

Initially, immigrants find it difficult to find appropriate employment because of perceived lack of facility in the dominant language, as well as skills and experience that are not perfectly suited to workplaces in the new country, and limited social networks (Ferrer, 2008). This has resulted in an initial decline in the labour market standing for them (Ferrer, 2008). As Bauder (2003) claims, non-recognition of foreign credentials and experience of immigrants by professional associations and employers leads to their active exclusion from the upper segments of the labour market. In this respect, what matters is attaining work in one's occupation (or one with higher status), and not of a lower status occupation.

While attending a recent symposium organized by the World Education Services (a nonprofit organization that evaluates foreign credential) I had a casual conversation with the individuals seated at my table about the term 'Canadian experience.' When I asked them, “What do employers mean when they say you're lacking Canadian experience? Do they even know 
what they're looking for?” I was not surprised to see that everyone sitting around the table responded with laughter and said "No." These individuals were involved with internationally trained professionals and foreign credential recognition in various ways, so it was not simply the opinion of a representative of World Education Services. In a liberal, democratic country like Canada, de-valuing international human capital not only robs the economy of valuable resources in a global environment, it undermines the skills of those who are unemployed or improperly employed, degrading their professional self-esteem.

In the teaching profession there is already an over-supply of trained teachers and not enough job openings. Internationally trained teachers are further disadvantaged in their search for teaching positions for a variety of reasons, including their accent (Schmidt, 2010). When they do not find jobs in the profession they were trained for, they seek the credentials for working as Early Childhood Educators (ECEs) and look for positions in the field of childcare

ECEs in Toronto include a significant number of foreign-educated teachers who work in childcare centres or run their home daycare (Maitra, 2011). Shan (2009) found that Chinese immigrant women who had worked as engineers and lawyers in China, also ended up working as ECEs because the professional training takes a shorter time, has lower entry requirements, and is more affordable. My own experiences as a student from India, who worked as an ECE in Ontario and now as a settlement worker led me to the question, "How does the professional identity and practice of elementary teachers from India change when they work as Early Childhood Educators in Ontario? 


\section{Context}

Contexts shape experiences and understandings. It is therefore important to begin this paper by describing the schooling system in India and the childcare system in Ontario.

Early Childhood Education in Ontario, Canada

Early Childhood Education practices and models in Ontario are based on Western ideology, culture and research. Traditionally, the term ECE referred only to the teaching and supervisory staff in a child care setting. The profession has since evolved and individuals trained as ECEs also work as trainers, consultants, and staff in government and non-government institutions. ECEs work in a variety of early learning and care programs and related services such as child care centres, home child care, school age programs, special needs programs, parenting centres, government licensing services and ECE training institutions or agencies. According to the Association of Early Childhood Educators in Ontario (AECEO) the Early Childhood Educators Act of 2007 requires that an individual wishing to become an Early Childhood Educator in Ontario must be trained in a program accepted by the College of Early Childhood Educators (College of ECE), and must be a member of the College. The professional titles of Early Childhood Educator (ECE) and Registered Early Childhood Educator (RECE) are protected titles as per the conditions set by the College of ECE (http://www.aeceo.ca/). The Association of Early Childhood Educators Ontario (AECEO) defines an Early Childhood Educator (ECE) as:

1. a practitioner responsible for the development and implementation of activities in a variety of early learning and child care settings for children from infancy to school age. ECEs are responsible for planning and organizing activities that protect and promote children's intellectual, physical, social and emotional growth. 
2. an administrator who is involved in supervising practitioners (as above) or in a supervisory role involved in indirect work associated with young children and families

3. a trainer who is involved in training and educating student practitioners, practitioners or administrators (as above) in their professional role.

Following graduation from an appropriate program in a college or university, the student is granted a diploma or degree in Early Childhood Education. However, in order to become a certified preschool teacher/ECE, the student must first complete one year of full-time teaching in a childcare setting. Secondly, the student must approach the AECEO and ask to be evaluated. Additionally, that individual must be registered with the College of Early Childhood Educators (CECE). The CECE is for public protection and for ensuring that the Registered Early Childhood Educator (RECE) professionals meet the standards for providing high quality service for the children and families that attend their programs. Once hired, the ECE must adhere to the Ontario Day Nurseries Act (DNA) and Regulations. The DNA focuses on things such as physical space requirements (indoor and outdoor spaces); procedures for medication handling, storage, and dispensation; enrollment and record keeping, schedules and forms; ratios between staff and children; licensing; health of staff; and even a section on building and accommodation for children who are handicapped. Through this, it appears evident that the focus is strictly on regulations and quality assurance and assessment (Day Nurseries Act, 2013).

The landscape of early year's education within Ontario is undergoing dramatic shifts. Historically, early year's education and care (birth to age five) was addressed within the social care sector under the directive of the province’s Ministry of Children and Youth Services (MCYS). In 2010, Ontario began implementing full-day early learning within the formal schooling system and as a result, ECEs began to be hired by School Boards. A teacher and an 
ECE are now required to work together in kindergarten classes in Ontario. The roles and responsibilities of early year's educators and teachers remains a divisive issue. Early childhood educators are required to hold a two-year college diploma (and accreditation from the College of Early Childhood Educators) and kindergarten teachers need to complete a university-level degree and have licensure from the Ontario College of Teachers (OCT). These teachers can be solely responsible for their classroom. However, an ECE cannot be responsible alone for a kindergarten classroom within the school system. Another significant difference between the two is in their salaries (Tozer, 2012). Whether they work in schools or in childcare settings, ECE are paid at a lower rate than teachers. As de Leon-Carillo, (2007) and Sumsion (2007) have noted, they are not considered 'real' teachers. Their working hours and other working conditions are also quite different.

A third difference is the incompatibility of some established school policies and practices with the pedagogy and philosophies of early childhood education. In one example of this, Gananathan (2011) notes that the ‘no-touch’ policies were mainly put into place in schools to deter educators from using excessive force in disciplining their students. The researcher provides four examples in which ECEs working in schools were advised to avoid touching students in situations where, in childcare with the same age children, they would have used physical contact as part of their professional practice. These examples include sending a child home because the ECE was not permitted to clean vomit from a child's clothes, not being able to take a crying child onto her lap to calm her, no assistance during bathroom accidents, and no hand holding.

Today each of Canada's provinces and territories has a variety early childcare education programs and services rather than a coordinated early childhood program like that found in France, Belgium, Denmark or Sweden for example (Doherty et al., 2002).There are various types 
of daycare centers in Ontario ranging from non-profit to for-profit, and "lab schools." (See Appendix 1). The daycare where observations for this project were done is a for-profit daycare. Growing research in this field has verified that non-profit childcare is better in quality, in large part because of the tendency of for-profit programs to "skimp" on a wide range of quality indicators, including the quality of staff (Prentice, 2005).

The setting in which Shammi and Leena (the participants in this project) currently work is a privately owned for-profit daycare run by a Canadian corporation. Funtime (pseudonym) has various locations throughout the province. Apart from the co-owners of the centers, there are regional managers who visit each center in their region on a weekly basis to offer support to the supervisors and the center. All Funtime centres accommodate infants to kindergarteners. All locations are fully licensed by the Ministry of Child and Youth Services and meet the requirements set out by the DNA. A unique feature of Funtime is the provision of Video Over the Internet (VOI) to parents and caregivers. There are two cameras in each classroom and parents have access to the classroom their child is enrolled in. In addition, Tablet are provided in each classroom for teachers to sign in/sign out children, record their milestones with pictures. The picture is uploaded immediately with comments from the teacher. The Ministry does not consider the Tablet as a credible source so all the teachers have to do similar work (sign in/sign out children) on paper as well.

The specific location where this study was conducted is close to a GO station and surrounded by corporate offices, where most of the parents work. There are very few ethnically diverse parents associated with the center. However, most of the staff working at this location are immigrants from various parts of the world, and many of these women were teachers in their countries of origin. 


\section{Schooling in India}

The schooling system in India is not homogenous. In most states in India, there are government schools, funded and managed by the central or state governments or by local bodies; private schools that charge school fees and are funded and managed by private entities; and semi-private schools, set up by private entities or trusts but aided by government funds, feecharging but subject to government rules and regulations (Kingdon, 1996).

Some urban private and semi-private schools are highly regarded and many more parents apply for admission to the school compared to the available spaces. Parents are interviewed and children are tested for admission to the nursery/kindergarten grades in these schools, and getting admission into some of the more elite schools is very difficult (Gupta, 2008). Such schools are reputed to have high standards with regard to curricular and pedagogical practices, abundant classroom materials, and excellent teachers. Teachers in these schools are given a great deal of respect not just by the students but by their parents as well. Consequently, the teachers hold a great deal of power and prestige. Intentionally, or unintentionally how they view themselves is

also a reflection of the societal gaze. It is in these schools that the most affluent families are able to send their children. The language of instruction in these schools is English, which is still considered a language spoken by the elite class of India.

The role of a teacher in India is different than the role of teacher in the West. Rooted in the ancient scriptures and philosophy of India is the relationship of the guru-shishya (teacher student). Hence, many of the concepts such as sharing, kindness and honesty are included in the domain of child development. These concepts in the West are attached to the socio-emotional development of a child whereas they are seen as “values” by teachers in India (Gupta 2006, 62). Due to the exam-oriented nature of the educational system as a whole, teaching academics is one 
aim of education that is prioritized in all schools in India (Gupta 2006, 68). The strict teacher is respected for imposing high standards, which the child will learn to meet. Due to the respect traditionally accorded to a teacher in India, a level of authority is automatically conferred upon teachers on the basis of their professional status.

Given that the majority of the population in India is Hindu, they believe that the scriptures of Hinduism are not simply religious and spiritual activities, rather they are viewed as guidelines on how to live a balanced and successful life. For example, in the Hindu tradition parents are considered reincarnations of God. Similarly, a teacher is given the status of a guru. The literal meaning of this Sanskrit term Gu-ru is to lead one from darkness to lightness. In the broader spectrum it can have many meanings such as guiding one from ignorance to knowledge (Gupta 2006, 93) or a spiritual guide and mentor and a teacher in the pedagogic sense (Kale, 1970). Goddess Saraswatiis worshiped for granting knowledge, wisdom and learning. It is important to clarify that knowledge and learning and the role of a Guru in India is not limited to academics, but also encompasses the field of performing arts, including playing instruments, learning the form of traditional dances which depict the stories in the scriptures and singing and chanting mantras. In a society where knowledge and the knowledge giver have equal respect as parents, it is unthinkable to show disrespect towards teachers.

However, during the British Raj (reign) the Western image of the teacher, which was very different than the Hindu image, was introduced. Some of the events included the adoption of English as the language of instruction in all schools supported by the British administration (Gupta 2006, 64) which lead to a well-paying job. Kale (1970) discusses the contradictions and dilemmas of status and role of a teacher as a result of colonization. She examines a variety of occupational identities and self-images of the teachers, such as the traditional Indian Guru, the 
modern western pedagogue, the professional, the academic salesman and the bureaucratic functionary.

In a society where academic success is considered critical to future professional success, the goal of teaching is seen to prepare students for state and national examinations, and teachers' success is measured in terms of grades achieved by their students. However, in a comparative study of teacher's ideology of professionalism in India and England, Chaturvedi and Ginsburg (1988) found that teachers in India did not think they 'wielded authority.'

Despite the historical views about teachers in India, they are currently not viewed as scholars or intellectuals. Most of the student-teachers at training colleges hold Bachelor's degrees with low grades (Kale 1970). They are seen as mediocre persons with college education but without any scholastic distinction, who, for want of another career, become teachers. In some private schools in New Delhi the principal's main reasoning for hiring a teacher in the primary grades was more related to the teachers' own personal characteristics, rather than on the educational degrees (Gupta 2006, 108). Private coaching classes, tuitions to individual students on a fee basis, and writing of study guides and 'cribs', which are looked upon as commercialism by teachers and non-teachers alike, reinforce this view of the 'less scholarly' teacher. The tuition or coaching class teacher tries to give the student an effective examination technique, based mostly on memorization of ready-made answers (Kale 1970).

India is currently experiencing a major shift with regards to the way teaching and learning is practiced. On one hand, there exists a history of more traditional and authoritative teacher directed classroom pedagogical practices and on the other hand, the National Curriculum Framework (NCF) introduced in 2005 is advocating heightened attention to child-centered and constructivist classroom pedagogical practices (Mir, 2013).It was only with the establishment of 
the modified National Policy on Education (NPE) in 1992 that the urgently needed attention was given to Early Childhood Care and Education (ECCE), and with this came the formal recognition of early education playing a critical part in the development of human resources (Gupta, 2008). The development of ECCE programs was seen as not only providing the individual child with early care and education, but also releasing women for other activities besides child-rearing, and facilitating the access to schools by older girls who would have been otherwise providing sibling care (Gupta, 2008).

ECCE in India falls under the purview of various departments such as the Department of Women and Child Development (DWCD), District Primary Education Program (DPEP), and the Department of Elementary Education and Literacy (DEEL) (Gupta, 2008). Thus, the field of early education in India is multi-tiered and complex, and encompasses a wide variety of schools. Nevertheless, most teachers who teach young children in private or semi-private schools are still regulated by the Department of Education and all rules and regulations that apply to other teachers in the same school also apply to them.

\section{Theoretical framework}

In order to appropriately capture the scope of the complex concept of 'identity' a combination of various theories will be used to guide this paper. Grounded in the social constructionist framework, this research takes an interpretivist approach to understanding the immigrant women's professional intercultural experiences. An interpretivist perspective focuses on the symbolic processes of social construction and emphasizes that "reality is socially constructed through the words, symbols and behaviors of its members” (Putnam, 1983, as cited in Bartesaghi \& Castor, 2008, p.6). The intersection of the immigrant professionals' class and 
ethnic/race background in the host country and the global context create complexity in their intercultural experience and identity negotiation. Therefore, I chose to examine their identity negotiation through a narrative methodology.

I examine the process of Indian immigrant professionals' identification in-between two identities: teacher identity in India and early childhood educator identity in Canada. This inbetween perspective recognizes the multiple relationships in which immigrants engage for their identity negotiation. It does not assume a priori any single relationship as the only or the most important context for identity negotiation.

Another theory that will be used to analyze the deep concept of identity in terms of immigration is the Human Capital theory. Human Capital theory proposes that the human capital that an individual has, such as credentials and skills, should translate into economic gains (Jenkins, 2002). However, Human Capital theorists argue that the capital of some individuals in society is undervalued, and they are in turn systematically denied of their rightful economic gains (Moore, 2008).

Research has finally started booming in the field of immigrants trying to adjust in a new environment and how it affects their professional identity. Hence, Social Identity theory is another framework that will be used in this thesis. According to Gergen (2001) Social Identity theory holds a conception of multiple and evolving identities as on-going and situated construction. Studies on teacher identity have begun to focus on membership and social intelligibility, which involves on-going construction and negotiation (Kostogriz \& Peeler, 2004). For immigrant teachers working in unfamiliar school settings, the issue of membership and social intelligibility stands out as they navigate between two different cultures, and social marginalization is often observed in their professional lives (Beynon et al., 2004). In their 
processes of negotiating the new school context, immigrant teachers are often confronted with the competing academic practices in their background cultures and in the new school contexts (Myles et al, 2006), such as the "Canadian pedagogical style" and "child-centered methods," although the meaning and nature of these practices are seldom clearly defined, and their relation to the situated practices unexplored.

\section{Literature review}

Below is are view of the literature regarding some of the common barriers to labour market integration faced by immigrant professionals in general, women from South Asia in particular, and those working in the professional of teaching specifically. The concepts of identity, particularly professional identity are also explored.

\section{Challenges of immigration}

As a country of immigration, Canada has been experiencing a confusing trend for some time. On one hand, since the introduction of the points system in the late 1960s, public policy has increasingly encouraged immigration of skilled individuals with higher levels of education, official language proficiency, and work experience. As a result, each new generation of immigrants has been arriving with an average level of education higher than that of the preceding generation and that of the Canadian-born population (Türegün, 2011). On the other hand, with the new Immigration and Refugee Protection Act (IRPA) legislation introduced in 2002, Citizenship and Immigration Canada (CIC) moved completely away from the attempt to meet short-term labour market objectives through the Federal Skilled Worker program (those being selected for specific professions). Instead, they strengthened the "human capital" model of 
immigration that rewarded skills such as general education, experience and language ability, rather than specific occupations (Ferrer et al., 2012).

In 2006, for example, 51\% of recent immigrants had a university degree compared to 28\% of earlier cohorts and 20\% of the Canadian-born population (Chui, 2011). However, immigrants’ economic performance has steadily deteriorated since the 1980s. Using aggregate data, economists have gathered evidence for the widening gap in employment earnings and wealth between recent immigrants and other participants in the labour market, former immigrants and the Canadian-born alike (Schellenberg and Hou 2005).

\section{Challenges for immigrant women}

Between 1991 and 2006, more highly educated immigrants with university degrees have come to Canada and are more likely to be from South Asia or South East Asia and women arriving from these countries have also been equally qualified (Maitra, 2011). According to a report by Timothy Owen (2001) on labour market trends of immigrants in Canada, in 2001 37\% men from South Asia, and 48\% women from South Asia had a university degree but were working in jobs requiring only a high school education. The corresponding numbers for all women in Canada were 55\% percent and 61\% (Owen, 2001). South Asian women thus, continue to experience the phenomenon of ghettoization and segmentation, which achieve both a divided workforce and a cheap, captive labour pool. Despite possessing university education, and several years of professional work experiences, South Asian immigrant women have had a difficult time translating those skills into appropriate work opportunities in the new country

More specifically, research has pointed to a widely held view among the Canadian public, regulators, and employers that immigrants from 'third world countries' hold inferior or alien human capital (Reitz, 2001). In 2008 the Ontario College of Teachers (OCT) reported 
certifying "record numbers" of internationally educated teachers in recent years; yet, only 7\% of so-called "new-Canadian" teachers found regular teaching jobs in Ontario publicly funded schools in 2007 compared with 29\% of graduates overall (Cho, 2010). As a result, there is an over-representation of highly educated professionals in low paying jobs, represented by the symbolic figure of the Pakistani taxi driver with a PhD on the streets of Toronto.

Additionally, the tendency of Canadian regulatory organizations to appreciate Canadian credentials over foreign degrees suggests that these organizations seek to reproduce their own membership of Canadian-born and educated professionals by excluding foreign-trained immigrants (Girard and Bauder, 2007). In their research on the certification of immigrant teachers in British Columbia, Benyon, Ilieva, and Dichupa (2004) found that, "the BCCT [British Columbia College of Teachers] operates as a gatekeeper, authorized to ensure that teaching positions in mainstream schools are filled by individuals who will transmit the cultural capital of the dominant society.” This reflects an image of the typical white female who is, middle class, heterosexual, able-bodied, Christian and Canadian-born, still teaching in most classrooms. Furthermore, these actions promote the notion of white privilege in a 'multicultural' society and reinforce the attitude of 'us' versus 'them.'

The job market in Ontario has been challenging for internationally educated teachers who obtained their initial teacher education outside of Canada (McIntyre, 2011). A recent study by McIntyre (2011) indicated that the unemployment rate for first-year teachers in Ontario has grown from 3\% in 2006 to 24\% by 2010. The underemployment rates for teachers who had a teaching position in the first year rose from $27 \%$ to $43 \%$ over the same period and in the school year of 2009 to 2010; only 26\% of newly qualified teachers had regular teaching jobs (McIntyre, 2011). Although many internationally trained teachers received certificates from the OCT, very 
few found jobs in Ontario school boards. Among these teachers who were licensed to teach in Ontario in 2009, 68\% could not get jobs (McIntyre, 2011).

Although some efforts have been made by the Canadian government, teacher education programs, researchers and educators to diversify the teaching profession, research showed that there is a gap between the policy making and policy implementation regarding the hiring of internationally educated teachers (Schmidt \& Block, 2010). The number of racialized teachers and school counselors in Canadian elementary and secondary schools has not kept pace with the growth in the number of Canadian citizens of colour and the number of students of color in school (Ryan, Pollock \& Antonelli, 2009).

Immigrant women often come to Canada as accompanying spouses and dependants of economic immigrants. Minority feminist scholarship shows how minority women's experiences in family, education, and career development differ from minority men's experiences (Benyon and Hirji, 2000). Between family and work most immigrant women attend to family responsibilities first (Wang, 2008). Additionally, when there is a question of survival, most women take jobs that provide them financial means to make a living, no matter whether it matches their former training or not. Hence, obtaining paid employment at the early stage of immigration is an obligation for women, as they provide financial means for the survival of their family (Wang 2008).

A smaller proportion of immigrant women (48\%) had their work experience recognized by an employer, a work-related organization or an educational institution, as opposed to (56\%) men (Houle and Yssaad 2010). In her study of Chinese immigrant women in Canada, Shan (2009) discovered that even though some women found jobs related to one kind of training that they received in Canada; all of them were employed at a level lower than their occupations in 
China. Additionally, she found that even though some of these women were working in male dominated fields such as engineering in China, they ended up in female dominated areas such as a childcare work in Canada.

The cost of examinations and bridging courses often means that women decide not to continue with the process as they perceive this to be a selfish pursuit of their own interests. As they are the primary caregivers for their children or elderly people in the family, their own career aspirations are not prioritized. According to Iredale (2004) women are usually conditioned to putting themselves last and they feel that their partner's and children's needs are more important than their own. Professions that assess qualifications against current training requirements may disadvantage women who have been out of the workforce or not kept up with their field. Hence, it is equally important for immigrant women to continue their journey in their profession so their human capital is not wasted.

\section{Linguistic challenges}

Given the current demographic of educated immigrants entering Canada under the points system, most are competent in general English language skills. However, tests such as the TOFEL test for language proficiency, do not test for occupation-specific language and the subtle nuances of words, leaving many internationally educated teachers unaware of 'politically correct' discourses that they can draw upon when being interviewed for jobs.

Discrimination based on accent is a severe and common form of racism commonly used in the labour market. In her study Phillion (2003) found two participants (from India and Jamaica) who spoke English as a first language but felt that their accents were problems in interview situations. Participants in The Alternative Teacher Accreditation Program for Teachers with International Experience (ATAPTIE) stated their concern and worries mainly stemmed 
from their feelings that their non-native English accent might be a disadvantage for them when applying for elementary teaching jobs in Ontario schools (Myles et al., 2006). They also shared their frustration stating that foreign accent was linked to a linguistic deficiency model and comments about accents were hurtful and demeaning. As a result many teacher candidates struggled along or became silenced for fear of saying the wrong word in the wrong way during their practicum (Myles et al, 2006).This further exacerbated perception about them as unsuitable for teaching and they were not called back for supply work or hired for a permanent teaching position (Pollock, 2006).

Research has shown that many other internationally trained teachers have also had negative experiences regarding their accents (Cho, 2010; Myles et al., 2006). In her study of internationally trained teachers, Cho (2010) found that many of her participants had unsupportive mentor teachers during their practicum. She states that some mentor teachers and other associate teachers in the elementary grades raised concerns about immigrant teachers teaching young children (particularly kindergarten and grade one). "The rationale provided by some associate teachers is that primary students are acquiring English language skills and the modeling of “correct English” is paramount” (Cho, 2010). Additionally, not all accents are challenged equally, for example those of teachers from countries such as Britain, Australia, and Sweden were rarely questioned (Cho, 2010).But, Indian, Chinese or accents from other developing countries were questioned. Speaking with an accent is equated with an inability to communicate successfully along with making the educated teacher left with a feeling of being dumb. This feeling of always being cautious because of accent, choice of words, or immigrant status, has direct implications not only on the candidates' ability to perform, but also on their acceptance within a school community at large (Cho, 2010). Such circumstances reveal the ways in which 
dominant English speakers in positions of power are often unwilling to acknowledge their own bias and disrupt their subject-position privilege.

The lack of Canadian experience

Professional bodies, registration procedures and the hiring preferences of employers in particular sectors, all play a role in integrating immigrants into the Canadian labour market. Using The Longitudinal Survey of Immigrants to Canada (LSIC), which surveyed approximately 12,000 immigrants who arrived in Canada in 2000-01, Goldman (2009) found that immigrants obtain modest returns to their foreign schooling and no returns to foreign work experience. A similar finding by Dean (2010) confirmed that foreign education is found to be reasonably transferable in the Canadian labour market, but the discounted value of foreign experience is a serious impediment to the immigrant integration process. Not having Canadian experience limits opportunities for immigrants to integrate in the labour market, which has a direct effect on their overall integration process.

Similarly, extended periods of unemployment lead to lower wage attainment; both because immigrants are not gaining Canadian work-experience in these periods, and because such statuses may stigmatize immigrants as less attached to the labour market and/or less employable (Alboim and McIsaac 2007; Fuller, 2012). Immigration may present a desired opportunity to change occupations for some. However, for many, finding work in the occupation in which one was trained and has accumulated work experience is an important goal (Fuller, 2012). Failure to do so represents a critical rupture in career progress and identity that can be demoralizing in ways that go beyond pure economic calculus (Fuller, 2012). In this respect, what matters is attaining work in one's occupation (or one with higher status) not that of a lower status occupation. 
The point system treats any degree from any institution the same. However, when it comes to foreign experience it is a different story. Research has found that foreign experience may be treated as inferior to Canadian experience, since less is known about the employer and tasks involved (Ferrer, 2008). Additionally, employer decisions may be swayed by stereotypical gendered and racialized understandings of particular worker (in) competencies (Reitz, 2001).From an employer’s perspective immigrants lack soft skills such as communication, occupational language facility and the ability to fit in (Teelucksingh and Galabuzi, 2005). In the case of an internationally trained teacher, the common issue of classroom management, which involves establishing rules and routines along with dealing with misbehaviour, varies among different classrooms and schools (Myles et al., 2006).

\section{Identity and immigrants}

The term identity encompasses the following characteristics as derived from the Collins English Dictionary (2010): the state of having unique identifying characteristics held by no other person or thing, the individual characteristics by which a person or thing is recognized. According to Villagomeza (2009) identity as a broad concept, outlines all the characteristics that a person may logically claim about himself which may include but is not limited to his name, status, ethnicity, religion, family affiliation, profession, personality, past life, etc. A person may have multiple identities depending upon the number of relationships in which he is involved in. As a result, a man may have identities such as physician, husband, father, uncle, son, tennis player, etc. which when taken together comprise the person‘s self (Villagomeza, 2009). The construction of identities is considered to be fluid, rather than fixed (Foucault, 1981). Instead of a singular and fixed identity, Michel Foucault (1981) believes that a person wears multiple masks and performs identities in diverse and complex ways. The performance of a particular way of 
being reflects only one of these identities. When one mask is removed, rather than the discovery of the true or real identity, there are always other masks, other identities, shaped and maintained by discursive practices (Foucault, 1981). In the case of teacher, she can be interacting with the children and speaking in words they understand and the next moment when it is time to communicate with an adult a different mask is put on. In general, the concept of identity has different meanings in the literature of professional identity. What these various meanings have in common is the idea that identity is not a fixed attribute of a person. In this context, then, identity can also be seen as an answer to the recurrent question: “'Who am I at this moment?'” (Beijaard et al., 2004).

In dealing with the subject of black women and identity, Crenshaw (1993) wrote “...because of their intersectional identity as both women and of color within discourses that are shaped to respond to one or the other, women of color are marginalized within both” (p. 1244). In her study of internationally trained post-secondary educators trying to re-enter into the labour market, Baptiste (2013) found that discrimination in receiving societies are especially critical because immigrants from racialized groups can be vulnerable to discrimination in the labour market due to multiple exclusionary identities which come into play during the job search process. Exclusionary identities in a receiving society such as Canada might include English/French language challenges (including accent), physical appearance, and gender among others, as stated above. Any attempt to account for the challenges faced by new immigrants which attends to only one of these identities will fail to capture the unique configurations of oppression which are operative in a contemporary society such as Canada (Browne and Misra, 2003). Underemployment and over-qualification may be particularly troubling for highly skilled immigrants as they are granted immigration precisely because of their occupational identities, 
education, and work-experience. These identities are often central to immigrants' sense of self and the collapse or decline of these identities as a result of underemployment after immigration leads to enormous distress and frustration (Dean \& Wilson, 2009; Chen et al., 2010).

\section{Professional identities}

The notion of professional education for teachers got defined between the 1880’s 1930’s in the context of American higher education (Gulati, 2013). In her article, Gulati (2013) looks at the experiences of graduates of a professional teacher education programme in India. In her research she states that in order to gain a professional status it was considered important to have specific knowledge and expertise in a few specific occupations, which were related to applied fields directly. An occupation became a profession when it was clearly established in higher education. There were several consequences of this. Gradually, it became increasingly important to spend extended years in schooling before professional training could be undertaken. As a result of the creation of 'professionalization' a sequential pattern was established - first schooling, then college, and then training for professional occupation. Also, knowledge gained in academic settings became more important than work-based knowledge. This also led to higher education becoming a realm of the 'experts' and therefore, exclusive. The notions of professionalism in fields of study including teacher education include pertinent features such as, having selection procedures (as everyone could not become a professional), admission standards, increasing standardization in terms of course requirements and assessments, certification and licensing examination and research specific to the field (Gulati, 2013).

The concept of professional identity of teachers is not only about the conceptions and expectations of other people, but also includes their own notions about what a teacher should know and do(Tickle, 2000). The interaction between a teacher’s biography, her immediate 
environment, and the societal setting shapes her professional identity (Wagner, 2010). Thus, to understand the professional development of early childhood teachers, one must consider not only the individual teacher, but also the relationships and environments that influence who the professional is as a person (Wagner, 2010). Lortie's $(1965,1975)$ research highlights the influential role that being a student plays in becoming a teacher. Unlike other professions, teacher's preparation of themselves as teachers begin early in life and thus "their entire school experience contributes to their work socialization.” (Lortie 1965, p. 56 as cited in FeimanNemser, 1983). Elbaz (1981) further explains that teachers' experiences as schoolchildren, as well as what they witness during their practical training, helps them construct strong images in their mind about what teachers' work looks like. They draw upon their images to construct their own practice as teachers (Gupta 2006, p.133). Lortie (1975 as cited in Feiman-Nemser, 1983) recommends future teachers be helped to examine their past to see how it shapes their beliefs about their own teaching. Additionally, Villagomeza, (2009) while quoting Collier (1998) points out that postmodern and cultural studies of identity concentrate on structural factors such as race, class, and gender at the expense of social interactional episodes of identity construction (i.e., the meaning-making processes that constitute shared group membership). The theme of teacher identity has only recently begun to attract the widespread attention of researchers in the area of teaching and teacher education.

Research on teachers' professional identity formation contributes to our understanding and acknowledgment of what it feels like to be a teacher in today's schools, where many things are changing rapidly, and how teachers cope with these changes. What is relevant to the profession, especially in light of the many educational changes currently taking place, is that new practices may conflict with what teachers personally desire and understand as good (Beijaard et 
al., 2004). Researchers who have studied identities of teachers (Day et al., 2006; Beijaard et al., 2004) have tried to understand Mead (1934) and Erikson's (1926) view of the 'self' and situate it to define identity. For example, Mead (1934) believed that the self, though stable, was a “...continuous concept closely linked to social interactions and created through language and social experiences and the environment.” Erikson (1968) on the other hand, outlined a chronological and changing concept of identity stating that “...identity is not something one has, but something that develops during one's whole life.”

Building on their work, Jennifer Nias's (1989) research is considered a foundational piece of analysis that focused on the primary school teacher's idea of self. Nias's main contribution was to identify a distinction between the personal and professional elements of teachers' lives and identities. Her research also concentrated on the tensions and contradictions in the primary teacher's role, which are principally produced through the opposition between the impulse and requirement to 'care and nurture' and the impulse and requirement to 'control.' However, the conflict between the values which inform individual teaching and the teaching of children as individuals continue to exist, as well as the institutional requirement to control, manage and teach children in a group, meet externally established 'standards', and deliver a curriculum (Day et al., 2006).

In her study of internationally educated teachers Zhao (2012) concentrated on important factors such as coping mechanisms during employment seeking experiences and their motivations to enter into the teaching field in Canada. Through her narrative study of 12 participants from different countries she found that participants who were identified as being 'very satisfied' with their career development, embraced the immigration and re-training process and experienced profound personal growth as a result. The participants spoke of becoming "more 
than what they were”, of becoming "confident in their ability to survive” and fulfilling their potential. All of these reflections describe deeply meaningful experiences. For example, one of the participants used to teach Physics at a college level in Pakistan. In Canada, she worked at various call centers and later worked as a teacher assistant in a private school (Zhao, 2012). However, in reality, most educated immigrants struggle to have a positive attitude towards the reconstructionor negotiation of their new identity. In trying to balance the personal and the professional identities, Coldron and Smith (1999) pointed to the tension between a matter of the teacher being seen as a teacher by himself or herself and by others and of redefining an identity that is socially validated.

\section{Identity as ECEs}

While much work has been done outlining the structural context of caregiving and the processes pertaining to the caregiver's relationships with children and parents, less is known about how caregivers integrate their professional experiences into their views regarding children and childcare. Tending to the experience of caregivers is important since, as daycare centres grow and multiply, so does the population of caregivers (Coxe et al., 2008). If we understand the needs of the caregivers better and try to address them, it will in turn be beneficial for the children. In their study of how daycare providers perceive themselves in the United States, Coxe et al., (2008) found that a combination of factors shapes the caregivers' view of their work. For example, when asked what could be done to improve the daycare experience for children and staff, many caregivers mentioned the “usual suspects”" such as the need for improved pay and the importance of lower adult child ratios. When asked about their profession's benefits, caregivers emphasised its emotional and relational rewards. In order to strengthen both respect 
and professional status for ECE workers, it is important to get a better idea about the ways in which early childhood professionals perceive their roles and identities.

Osgood's (2004; 2010) work in the United Kingdom highlights that a focus on professionalization of the ECE workforce is essential if we are to understand more about the ways in which reforms are conceptualised and implemented. As Woodrow (2007) cautions, the most recent developments in the Australian regulatory context, with the emergence of increasing surveillance and regulation, have the potential to impact the professional identity, status and preparation of the ECE workforce.

\section{Methodology}

This section describes the methodology used in this study. Describing my reasons for using a qualitative approach, I then move to discuss the importance of case studies. Next, I explain how I collected, transcribed and analyzed my data. I also outline some limitations and challenges I faced.

\section{Approach}

To answer the question "How does the professional identity and practice of elementary teachers from India change when they work as Early Childhood Educators in Ontario?” a qualitative approach is the most appropriate choice for this study. In his book titled, Qualitative Research Methods for the Social Science, Berg (2007) refers to qualitative research as an approach which responds to questions related to “...what, how, when and where of a thing - its essence and ambience...[It refers] to the meanings, concepts, definitions, characteristics, metaphors, symbols and description of things” (p.5). He describes qualitative researchers as those who "...are most interested in how humans arrange themselves and their settings and how 
inhabitants of these settings make sense of their surroundings through symbols, rituals, social structures, social roles and so forth.” (p.8). According to Creswell (2009) qualitative research is a “...means for exploring and understanding the meaning individuals or groups ascribe to a social or human problem...this style of inquiry supports a way of looking at research that honours an inductive style, a focus on individual meaning, and the importance of rendering the complexity of a situation” (p.4). The purpose of this study is to understand the participants' personal experience in terms of their professional identity, and to describe, in detail, “...the phenomena as they are situated and embedded in local contexts” (Johnson, 2004). Johnson (2004) also points out that qualitative data in the words and conceptual categories of participants lend themselves to exploring how and why phenomena occur and to determine the perceived cause of certain events. My research question is about the creation of a new professional identity or modification of a previous identity for teachers who have migrated from India now working in Ontario as ECEs. Qualitative data will give me insight into how my research participants interpret and compare the two professional identities from their past and present.

\section{Strategy}

A case study is a strategy of inquiry in which the researcher explores in depth one or more cases, representing individuals, organizations, or other bounded systems (Creswell 2009, p.16). For this study, I have used the multiple case study as a research strategy to study two individuals, using in depth interviews and observations to help construct each case. Cases are bound by time and activity and researchers collect detailed information using a variety of data collection procedures over a sustained period of time (Creswell 2009, p.17). In this study, I conducted two interviews, with each individual approximately eight weeks apart. Between the two interviews, I observed the individuals at their workplace over a period of three days, for 
eight hours each day. According to Berg (2006) this study would fall under the intrinsic case study category. "Intrinsic case studies are undertaken when a researcher wants to better understand a particular case...because of its uniqueness or ordinariness that a case becomes interesting...the intention is to better understand the intrinsic aspects of the particular case (Berg 2006, p. 291). In order to better understand how the former teachers, now working as ECEs characterized their professional identities it was important not just to talk to them at length, but also to observe their everyday practices, so our discussion could be located in a specific context, from which examples could be drawn for illustrative purposes. Since each case is unique, its study is not designed to generalize to other situations but to develop an in-depth understanding of the particular case. As Sandelowski (1986) has explained, generalization in case studies is an illusion because every situation is made up of a particular researcher in particular interactions with particular informants. Applicability (or transferability), then, is not seen as relevant to this kind of research, because its purpose is to describe a particular phenomenon or experience, not to generalize to others (Krefting, 1991). Nevertheless, case studies generate some new conceptual categories, which can be used to study other situations.

\section{Trustworthiness}

In case studies trustworthiness is assessed only in terms of how well the data represent the case that is under study. I tried to enhance the trustworthiness of my data by conducting the interviews and observations in a setting which was very familiar to the participants, and where they were comfortable speaking to me, and letting me observe their practice. During the observation I was not just a fly on the wall but assisted them when they requested me. This was done to show my appreciation for their willingness to talk to me and let me watch them in their classrooms. Another criterion of trustworthiness is reliability or dependability, which refers to 
the consistency of the data, that is, if the same research question was asked and the same variables were involved, would we get the same results? (Archer \& Berdahl 2011, p.135). In this case the combination of interviews and observations were helpful to ensure reliability in this study.

Credibility in qualitative studies refers to “....accurate descriptions or interpretations of the human experience that those who also share that experience would immediately recognize the descriptions” (Krefting, 1991). In other words, data collected must 'fit' the world being described. Member checking is a method I used to ensure that my findings were credible. Member checking is a technique that consists of continually testing with informants the researcher's data, analytic categories, interpretations and conclusions (Krefting 1991). Before exiting the interviews I re-read the notes I had taken to ensure that whatever I had written was exactly what the participants had explained and that my interpretation of some concepts was not just my opinion. Moreover, by doing this process the participants were able to add extra comments and points they remembered as I read my notes to them.

Conformability in qualitative research refers to “...steps taken to ensure as far as possible that the work's findings are the result of the experiences and ideas of the participants and not that of the researcher” (Shenton, 2004). In addition to member checking, I shared my expanded notes with my supervisor who is an experienced researcher and an expert in this field. As a result of the many questions she asked during our meetings I was able to carefully sift out my own opinions from the data that I had gathered.

\section{Sample and Recruitment}

Sampling in qualitative studies proceeds on theoretical grounds. This means that the researcher brings an idea that he/she wants to study, then selects groups or individuals most 
representative of that idea (Corbin 1990). In this study purposive sampling was used for the selection of participants. Purposive sampling involves the researcher's selection of specific cases that will provide the best information (Archer \& Berdahl 2011, p.173). This is to ensure that certain types of individuals or persons displaying certain attributes are included in the study (Berg, 2007 p.44). Purposive sampling is particularly useful with specialized populations that are difficult to reach or for populations that lack a sampling frame (Archer \& Berdahl 2011, p173).

For this study the participants were immigrant women who were teachers in India who are currently employed as childcare providers in Ontario. Furthermore, the cases (or participants) were selected to “...ensure that all the key constituencies of relevance to the subject matter are covered” (Archer \& Berdahl, 2011 p.173). Even though there is extensive literature on the effects of deskilling and devaluing of internationally trained professionals, I did not find extensive literature on former teachers from India now working as ECEs. In order to try to recruit participants for this research, an invitation flyer was posted in the staff room of the day care where I used to work. I would like to point out that I had not worked there for two years before returning for recruitment. In response to the flyer, two participants showed interest in the study and contacted me. In order to conduct the observations, a letter or permission was sent to the owner of the daycare. In the letter I had requested that when I have three participants I will stop recruitment. However, because of a lack of interest and time constraint I had to go ahead and begin the study with two participants. After receiving permission from the daycare owner I began my data collection.

\section{Setting}

This study was conducted in various locations. The first set of interviews happened in a public library room, where the participants at different times and individually discussed their 
roles as teachers in India. During this interview they also talked about their immigration process to Canada and discussed their 'struggle period' in in terms of overall settlement. (See Appendix 2 for interview 1 questions). The 'group study' room at the local public library was booked in advance. Throughout both the set of interviews I remained cognisant of the social pressure that can exist in interview environments which compel a participant to reveal information or opinions that they would rather not reveal. Therefore, the participants were reminded prior to and during the interview that they have the right to skip over any questions or to withdraw their participant at any point. Additionally, participants were reassured that pseudonyms will be used throughout the entire study.

After the first set of interviews the observations took place in the participants' classroom at the daycare for three consecutive days. The participants continued with their normal routines. I was not only observing but also helping out whenever they needed help. Meanwhile, I was tracking them in their professional setting (See Appendix 4). Tracking literally means following the guides around during their usual daily routines and watching their activities and other people they interact with (Berg 2007, p.196). Even though the observation happened in an environment with children, at no point during the observation were children observed. During the observation I was looking for my participants' interaction with the children. I was observing their voice tone, body language, and types of words they were using with the kids especially when giving instructions. The second set of interviews took place in the same library in the same 'group study’ room. In this interview the participants responded to open ended questions (See Appendix 3for interview 2 questions) about the observation. During parts of this interview participants were asked to do a comparative analysis about similar situations in India and how they would handle it. 


\section{Data collection tools and processes}

After getting approval from the 'Research Ethics Board' of Ryerson University, I went to the daycare and posted recruitment flyers. Throughout the research two key ethical issues were considered at all times, consent and confidentiality. The consent form (See Appendix 5) asked the participants to select if they wanted their interviews recorded and both the participants said no. Their consent was respected and all the data were hand written. In order to protect the identity of the participants, pseudonyms were used while the data were being collected and during the write up of the research. In order to conduct observation in the daycare a permission letter was sent to the owner of the day care stating the reasoning behind the observation and notifying them that no children will be observed at any point during the observation.

In order to get extensive data on this specific topic, a combination of narrative and ethnographic (observational) research designs were used. Narrative research focuses on studying a single person and gathering data through the collection of stories that are used to construct a narrative about the individual's experience and the meanings they attributes to them (Berg 2007, p.276). Using the narrative approach the first interview in this study was designed to create a profile of the participants. The questions were geared toward their overall journey from India to Canada, concentrating on their professional experiences. This process relied mainly on semistructured (open-ended) face-to-face interviews based on a set of questions I had prepared. Semistructured interviews are known to provide the best means by which respondents construct data about their lives (Graham, 1984, p.112). Moreover, semi-structured, open-ended interviews are more flexible (Fontana \& Frey, 2000) as they enable the participant to narrate personal experiences and organize information in a variety of ways not necessarily dictated by linear or 
temporal logic. This approach to interviewing allows for the depth, complexity and contradictory experiences of respondents, which structured interviews or questionnaires might hinder.

Observation research (ethnography) refers to observing behaviour in the natural environment (Archer \& Berdahl 2011, p.233) where the researcher collects extensive narrative data based on many variables over an extended period of time (Berg 2007, p.276). As a result, this design develops in-depth analytical descriptions of current systems, processes, and phenomena and/or understandings of the shared beliefs and practices of a particular group or culture (Berg 2007, p.276). Most of the second interview was based on the observations and to compare what was said in the first interview in terms of professional duties and expectations as the role of a teacher. In nearly all types of interviewing, a researcher designs the interview and collects the data. Face-to-face interviews offer more flexibility in terms of question content and, are more appropriate for long interviews with complex questions, and response options (Rizk, 2003). My interview guides gave these women the opportunity to voice their own thoughts, feelings, and emotions, something that has been hardly recognized in the literature on the professional identity of immigrants. In order to fully understand the shift in their practices and their identities it was important to conduct face to face interviews. The reason I chose to do interviews was because I felt that interviewing would give me an opportunity to have closer contacts with my informants and to document their life and career trajectories since immigration. Additionally, these interviews gave me a chance to probe for more information. The advantage of the second interview was that I was able to ask the participants why they did certain things in their classrooms; how that differed from their practices in India; and what that meant for their professional identities.

Analysis 
For the analysis of my data I used grounded theory which is used to “...generate or discover a theory...from data systematically obtained from social research” (Glaser \& Strauss 1967 in Corbin\& Strauss 1990). According to Corbin and Strauss (1990) grounded theory is ideal for exploring integral social relationships and the behaviour of groups where there has been little exploration of the contextual factors that affect individual's lives. Although there is research in the devaluing and deskilling of international credentials and experience in the healthcare and IT field, there is a lack of research for this specific group of research participants. Charmaz $(1995,2002)$ identifies a number of features that all grounded theories have. Although I did not use all the features identified by her, I did undertake the simultaneous collection and analysis of data. Before I conducted the observation and second interviews I used ideas that had emerged from the first interview to guide the subsequent interviews and observations. Additionally, I also wrote analytical memos between coding and writing, which is a feature of grounded theory. Most of the memos revolved around the participant's perception of themselves, including their identities and practices.

The analysis in this study involved managing the data by hand. In order to code by hand I read through the field notes a few times and identified common themes that emerged. The process of thematic analysis involves identifying themes and categories that emerge from the data. This involves discovering themes in the interview transcripts and attempting to verify, confirm and qualify them by searching through the data and repeating the process to identify further themes and categories. In order to do this, I expanded the notes I had taken during the interview immediately after I finished the interview, to capture the data as fully as I could. Then as I read each transcript, I made notes in the margins of words, theories or short phrases that sum up what is being said in the text. This is usually known as open coding (Burnard et al., 2008). 
The aim, however, is to offer a summary statement or word for each element that is discussed in the transcript. Additionally, to ensure I was taking advantage of the first round of data collection in the subsequent rounds I combined common answers that both the participants had given before conducting the next round. For example, from the first set of interviews some common answers that participants had given were around the child-teacher ratio in India, the short working hours and their high level of job satisfaction in India. Both the participants said they felt like working at a daycare made them feel like a "babysitter." My observation of their work allowed for me to ask them specifically which of their tasks made them think of themselves as babysitters and how that was related to their professional identity.

\section{Limitations}

One of the main limitations of this study was the small sample size in this research. However, there have been researchers in the past who have studied a similar idea and have been successful at pioneering concepts with less than three participants in their research (Oloo, 2012). The knowledge produced is not generalizable to other people or other settings (Johnson, 2004), which means that the findings are unique to the relatively two participants included in this research study. However, the ideas generated as a result of this work can be tested in other settings with more participants. Another limitation is that because I am from India and worked in the part in the same childcare facility, my participants may have not been completely honest because they felt I may be judging them. However, our commonly shared backgrounds, experiences and knowledge also helped me establish a rapport with my participants, and enabled me to communicate emphatically and understand their responses. As well, collecting data by hand limited me during my interviews as I was trying to listen and write simultaneously. This may have resulted in lack of collected of proper quotes. 


\section{Participant Profiles}

In this section I will first portray the two participants by presenting their profiles and some details. This will be followed by the general findings emerging from their interviews and observations. Together, these details will help to contextualize the abstract ideas arising from the data analysis.

Both female participants, Shammi and Leena (pseudonyms) came with their families under the points system from the same state of New Delhi, India. Both of them taught in the CBSE board, explained later during the paper. Even though their circumstances for immigration were different, both of them came in search of a better life. One of the participants came in 1992 and the other participant came in 2004. They immigrated at different times in their lives and met at the childcare center they are currently employed in. Although their personalities and teaching styles are very different, there are also some important similarities between the two.

\section{Participant 1 - Leena}

Leena completed her general education in India with a Bachelor of Arts degree specializing in Sociology. Following her BA she got her Bachelor of Education (B.Ed.) degree. Leena never wanted to be a teacher. Her dream was to be a lawyer. However, her father was not supportive of this dream because at that time it was a male dominated profession. Moreover, in the Indian culture it was not appropriate for a woman to step into a profession that is controlled by men. However, being a teacher is considered a respectful job for women in India. Leena was aware that she did not have a loud voice and as a result would have a hard time controlling the kids but she followed her father's advice. Soon after she got her B.Ed. she was married and soon after that her father passed away. After getting married she worked for one year in a Catholic school. To teach in a Catholic school in India one does not necessarily need to be a Catholic. 
When Leena was pregnant she stopped working as a teacher. Since she did not want to be a teacher right from the beginning, she used this opportunity to explore other professions. Leena enjoyed hair dressing and make up as a hobby and as a result she finished a beautician and aesthetics course. Soon after she bought a franchise, similar to Avon in Canada, related to beauty products. When her kids were old enough to go to school, she sent them to boarding school and returned to teaching. Alongside teaching, she would also do part time hair cutting in the evening.

Her school in India was a private and big institution that catered to all types of fields such as technical and arts. She taught Math and Art from grades 2 to 6 and Sociology to grade 7 . Since she had a B.Ed. she was able to teach up to grade 8 . She would also prepare the kids for skits and plays (drama) organized by the school. Overall, she taught 9 years, but not consistently, as she took time off when her children were born. Her curriculum was predesigned for the full academic year. She had to ensure the children knew the curriculum and there were pre-set routines, such as giving the children class work, and checking to ensure it was done in the same way that she taught them. Her work also consisted of giving the children home work and ensuring that was complete and done correctly. Additionally, she also had to do progress reports for four semesters. Since she was teaching different subjects she would have to go to the different classrooms when the bell rang. As a sign of respect, the children in each classroom that she would go to would stand up and greet her when she would enter and exit the classroom.

In India her work hours were from 7:30am-2:30pm. Leena worked Monday through Friday. Each morning her school would have a morning assembly where the entire school (all the grades up to 12) would get together and sing the national anthem and everyone was made aware of any special holidays, events or important announcements. After the assembly was over, all the kids and teachers would disperse to their own classrooms. In India, Leena got one period for 
planning which was 45 minutes as well as 30 minutes of lunch break on a daily basis. She also had to manage the attendance register where she had to tally it up at the end of each month and give it to the main office to ensure it matches with what they have. Also, when her school would organize educational day trips she would accompany the kids. When the kids would go to their PhysEd (PT) classes she would accompany them. Leena played the role of a classroom teacher and a specific subject teacher. While discussing her experiences she concentrated more on her experiences as a subject teacher.

In India, Leena was satisfied with her salary and benefits. Leena, got a B.Ed. grade salary in India which starts from 17,000 - 21,000Rs/month (bearing in mind the time period of when these figures were considered a decent amount). Her benefits in India included paid holidays such as 2 months summer vacation, 10 days winter vacation, 10 days of Diwali. Additionally, she also got any national holiday (August 15th, January 26th, October 2nd, etc.) and any Indian festival off (Holi, Diwali, Lohri, etc). She was also provided paid accommodation through the school. When she chose to send her kids to a different school, she did not have to pay any fees so it was free. On a scale of 1 (low satisfaction) to 10 (high satisfaction) she rated her job satisfaction in India an 8.

Leena came to Canada on a work permit with 2 young kids in December 1992. Her intention was to work after migration. However, her motive to move to Canada was to be close to her family as her spouse had passed away. She had her mother and brother in Ontario as her support system. Initially she got a job as a salesperson at Wal-Mart because such jobs were readily available. Soon after that, she was working as a book keeper and a filing clerk on a parttime basis at a small company. However, in order to get a full time position she upgraded herself and finished some Simply Accounting courses. As a result, the company she was working for 
hired her as a full time accountant and a book keeper. Furthermore, the company also paid for her to do some accounting courses at Sheridan College. In addition to these courses she also did an English equivalency course. She worked at this company from 1996 to 2006. She returned to Wal-Mart as a full time employee and also applied for a job at private school called Mississauga Christian Academy (MCA). Eventually, she got a call from MCA to work in their before and after school programs. She also did some administrative work at MCA. Gradually, she got involved in their SK classroom as an assistant.

During her time at MCA one of her colleagues told her about a bridging program at George Brown College. The program was called Early Childhood Education and it was a three years program. However, because of her experience from India and MCA she finished the course in one year through AECEO. Her entrance exam into the program included multiple choice questions, true and false questions. The exam also tested her listening ability and she had an interview after the exam to test her English skills. After her acceptance, in the first year Leena did three courses. In addition to the courses she did one placement, which was with school age children at Ryerson University. This was her first step into the ECE field.

\section{Participant 2 - Shammi}

Shammi attended Nursery Teachers Training (NTT) School and received a NTT certificate. Shammi was a nursery school teacher in the Central Board of Secondary Education. There are two Indian central boards, the Indian School Certificate Examination (ISCE) and the Central Board of Secondary Examinations (CBSE). In schools that prepare students for CBSE examinations, the textbooks are based on the syllabus prescribed for English within the National Curriculum Framework (NCERT, 2005). In Delhi, where Shammi used to teach, all teachers in government schools are affiliated with the CBSE and follow the books prescribed by that central 
board (Bhattacharya et al., 2007). As a result of being in CBSE she taught in English. She taught a junior kindergarten class where the age of the kids was 3+ and then she moved with them in their senior kindergarten class till they were $5+$. So she was with the same children for two years. Her school went up to grade 10. Her school was a reputed school. Her work hours were from 8:30am to 2:30pm with a 45 minute break. She had paid vacation from the school board. Her vacations included 10 days for Diwali, 2 months of summer vacation, Christmas holidays, and any other Indian festival and national holiday. On top of that she also had 10 casual leave days and 6 medical leave days that were all paid. She had a pension plan and a provident fund which is equivalent to the Canada Pension Plan. Even though her kids attended a different school than where she taught, she did not have to pay school fees for her kids. She had to pay for their books and uniforms on which she received a discount. Her medical benefits included a discount on certain hospitals that were associated with the board. She worked at this school for 11 years. Prior to that when she was unmarried she worked for 5 years in a different school. Her job was a government job so she got her salary from the government. It was not on an hourly basis. She was among the highest paid teachers within her salary range (keeping the time period in mind). Shammi's work week included weekly and daily planning. When she used to come to the school at 8:30 she would work on her daily plan based on the different periods that she was teaching that day. She would have assembly in her class where they would say a prayer and sing the national anthem. Her subjects included English, Hindi, Math, Art. She would accompany the kids when they would go for other classes such as Music, Computers, Horse Riding, Tennis and Swimming. She would eat lunch with the children. They would bring their own lunch. At 12:40 the children would go home. At that time she assisted with boarding the kids on the bus, auto, and taxi and to send them with their parents or guardians. She was responsible for sending the 
children home from 12:40 to 1pm. 1pm-1:30pm was the break time only for nursery teachers. 1:30-2:30 she prepared her class for next day, doing bulletin boards, fixing the attendance register, doing progress reports. By the time some or all of those tasks finished it was time for her to go home. She worked Monday through Saturday.

She was fully satisfied with her job. On September 5th every year her school celebrated teachers’ day, where lunch was provided by the school and then they had dinner with their spouses at a restaurant, paid for by the school. Before starting summer vacation the school provided lunch in a restaurant; similarly before Christmas vacation she went to a picnic organized by the school. Her school also organized an Annual Fete which is similar to an annual fair here, where they had rides, games, food stalls etc. Her school also had an annual day function in which the entire school participated. She also did parent teacher's interviews which were formal, similar to the ones that happen in the schools here. The teachers in her school organized sports day where the children ran relay races, participated in marching bands and competed in different sports. She attended workshops and seminars organized by the school for professional development. She also took the children out of the city for excursions and some of them were overnight trips as well. These trips were planned by the teachers. These were educational tours. Her job was to prepare the children for life, to be independent and not cling to their parents. On a scale of 1 (low satisfaction) to 10 (high satisfaction) she rated her job satisfaction in India 10.

Shammi came to Canada in April 2004. Her husband's factory closed in India. He applied through the points system as a skilled worker and got more points because of her language and work experience as his spouse. When she moved to Canada she thought she would supplement her husband's income. She worked in a salad factory for a month, then moved to a hardware 
factory. After moving in April 2004 she was unemployed for the first four months then she worked these survival jobs to support the family. When her husband got a good job in his field to run the family then she left these jobs. One of her colleagues from India moved to USA and got a job in a school there. She thought that if her colleague was able to get a job in the same field she can too. However, everyone she met in Canada told her to look at jobs in daycares. She was unaware of the rules and regulations in Ontario. Initially, she did apply to the school board as a 'nursery teacher' but didn't hear back so that's when she turned to daycares. When she didn't hear back from the school board, that's when her dreams were shattered. She would go to daycare centres and tell them 'I was a teacher in India and I would like to work with kids here.' She soon realized the reality of her downward employment status and labelled herself as a 'professional labour class’ person.

Shammi claimed there was no choice for her apart from working as an ECE. She had never worked anywhere else apart from a school, so that's all she knew. She started her preparation for ECE through AECEO. Similar to Leena, she also had to give a challenge exam. Her exam consisted for 110 multiple choice questions and three essay questions to test her English as well as true/false questions. She passed with flying colours and had to do 5 courses and two placements. The placement ages were preschool and OEYC.

\section{General Findings}

Interview and observation data from the study show that both the participants believed their professional identities and status had diminished as a result of the shift they had made from working as teachers in India to working as ECEs in Canada. They attributed this to three major changes i.e. in the nature of their work, in their working conditions, and as a consequence of 
aforementioned factors the institutional and societal respect accorded to them. Each of these is discussed in detail in the following sections.

Nature of work

Shammi and Leena talked at length about differences in the nature of their work as teachers and as ECEs. Shammi was not just a class teacher but also the 'supervisor' for all the section of the Montessori class she used to teach. She said that she used to:

... make the curriculum for everyone the within the ministry outlines...[I] was not only the class representative but also the supervisor for all the Montessori 1 classes which included 11 sections. So I had to make sure those 11 sections are following the curriculum that I planned.

In her current position she was only responsible for her own classroom, and did not mention any ministry guidelines that she used to frame her curriculum planning.

Shammi believed that the curriculum she was responsible for teaching in India included important knowledge and skills, which her students needed to learn to be academically successful. She said:

I taught the 3R's. Reading, reasoning (math) and writing are important for learning. This is learning that needs to be inculcated now at this stage only then they will keep doing it. When the child is ready to learn and they are showing us signs and we are not forcing them and we have eight hours which is more than enough time to learn and play, then why are we downgrading them?

She equated 'the 3Rs' with 'learning,' and differentiated that from play. By denying children the opportunity to learn the 3Rs during the eight hours they spent in the childcare facility, particularly when they were showing signs of being 'ready to learn,' was 'downgrading' them. In her view learning the 3Rs was clearly more valuable than just playing. Contrasting her role of a teacher, who helped children with worthwhile learning, with that of her role as an ECE, she said 
“...it is what is expected of me....whether they [the children] learn anything or not...I just play with them and interact with them.”

Both Shammi and Leena compared the curriculum they used in India as structured and standardized to the more or less unstructured curriculum they followed in the childcare centre. Leena pointed out that as a teacher in India she allocated 30 minutes to each subject i.e. English, Social Studies, Math, and Hindi and used textbooks for teaching these subjects. She also assigned homework to the children she taught and checked it the following day. In their roles as ECEs the former teachers said they had been instructed to leave the children to play and let them figure things out on their own. Activities they planned for the children were based on the children's interests, not predefined guidelines. For example, during the observations the theme of the week was animals, as some children in that room had shown some interest in animals. As a result, models of farm animals were stocked in the sensory bin, along with water and sponges so the children could 'clean' the animals. The provision of activities such as this were clearly very different from what Shammi and Leena had done in their classrooms in India.

Teaching children academic knowledge and skills was the primary - even exclusive purpose of Shammi and Leena's work in India. If they intervened in conflicts, or consoled or praised the children in their charge, it was always to motivate them to excel in their academic work. In contrast, here they found themselves working on developing the children's social and emotional competencies per se, as one of the main purposes of their work. During one observation, for example, Shammi was reading a book about pigs and ducklings. She interpreted the pictures in the book in terms of how the animals were feeling and asked the children questions such as “Do you think if someone did that to you, you would be happy?” On another 
day, a child arrived at the door to Leena’s classroom clinging to his mother. Leena said, “...its not nice to make mommy sad...” simply to encourage him to separate from his mother.

Physical care of the children or of their classroom was something neither participant had ever done, in their roles as teachers in India. Both of them said that in India children were already toilet trained before they came to school. However, if there was ever an accident, cleaning staff specifically employed by the school were responsible for cleaning up the child and the room. In their roles as ECEs, they had to diaper the children and help them learn procedures and routines for toilet training. They also had to set up the furniture and utensils for lunch and the two snack times every day and then clean up the tables and floors afterwards. In addition, they had to set up cots for the children to nap, and then stack them up again after the children's nap. Every week they also had to wash sheets and clothes from the drama centre, as well as clean and disinfect other play materials. As teachers in India, they had no cleaning responsibilities at all. Cleaning staff cleaned up the rooms every day after the children and teachers had left. If any of the rooms needed cleaning while the children and teachers were there, there was always someone available in the school to do this work.

According to Leena:

“here [in Canada] the child learns concepts like 'clean up.' In India, they had people who would clean up for you... [as a result] the teacher concentrated only on the child and the discipline."[However she felt] in a way its good here because the child is also learning concepts such clean up...”

During day 1 of the observation while Leena was cleaning up the morning snack she also had to resolve a conflict between two children. This practice was different than in India as both participants indicated that the kids would only bring their lunch to school. Shammi stated that, “...I would eat lunch with kids in the same classroom and they [children] would bring their own 
lunch.” Although both the participants eat with the children in their classroom here, they still have to set up the morning and evening snack, as well as lunch. After each of these times, they have ensure the classroom is clean, which includes sweeping and mopping after lunch.

Shammi and Leena assessed children's learning in both contexts, but what they assessed and how were very different. As teachers in India, they assessed children's learning by putting them through exercises which tested their academic knowledge and skills, and then formally reporting on their academic progress to parents and school administrators in writing. At the end of each term they also reported the children's progress to the parents through one-on-one meetings, which the parents were required to attend. In contrast, in their current positions they recorded 'milestones' achieved by the children by taking their photographs using the tablets provided. The childcare center had provided a set of milestones that Shammi and Leena had to adhere to when taking these photographs. These photographs were submitted to the administrator as records of the child's achievements and also used as evidence if parents came to find out how their child was doing. However, parent-teacher interviews were not a requirement, and many parents did not show up for such meetings.

Another major difference between Shammi and Leena's work as teachers in India and as ECEs in Canada was their role in 'disciplining' the children. Both of them believed that disciplining the children was as important part of their work. Shammi said, “...I think discipline is concentration; if you cannot sit you cannot learn. According to the Ministry and the Region of Peel circle time is supposed to be 15-20 minutes but it also depends on the kids too."It seems that Shammi associated discipline with teachers setting rules, regulations and procedures in the classroom, which the children had to follow. Observation notes taken in her class show that she used a loud and stern voice to give instructions to the children. During circle time she told 
children where to sit - in two rows - and how to sit. If they wanted to say something, she insisted that they raise their hand and wait to be called upon by her before speaking. On another occasion when Leena and she were talking about disciplining children she said:

...here we just provide materials and they will learn on their own through the play based learning. They need discipline and need to learn how to concentrate in order to learn. This is the age when they can learn.

Leena's approach was a little more casual. Speaking about her tone in interacting with children, she said, “...both loud and soft voices should be acceptable...[we] should talk to them just like they are family, sometimes loud and sometimes soft.” However, during my observation I noticed that she was trying to get one of the children to lay down to take a nap, but the child started playing with a toy. In a firm voice Leena whispered, "Stop it. Go play on the table quietly right now, 1,2,3..”

Leena acknowledged that her current workplace was different from a school, where children are expected to follow a predetermined curriculum. However, 'structured programming time’ was a part of her regular routine in the classroom. During this time I noticed Leena used phrases such as, "You're not doing it properly” when interacting with some children. When I asked about what she meant when she when used phrases such as these, she responded by saying that, “...this is not a formal school with a one size fits all model...its more open concept where they are playing...expectations from kids here are different and you deal with their needs accordingly.” It seems that there was discrepancy between her desires to have the children learn to do things 'properly' and simply letting them play. 


\section{Working Conditions}

Shammi and Leena spoke at length about the differences in the working conditions, when comparing their roles as teachers in India and ECEs in Canada. They made comparisons between their salaries and benefits, hours of work, and other related matters, which are described below.

As in other countries, teaching in a school is not a well-paid profession in comparison to other professions that require similar levels of education and training. However, it is a profession selected by many women for a variety of reasons, such as relatively shorter hours, and working with other women and children. Salaries for teachers have also increased a great deal in India compared to when Shammi and Leena were working there. However, both of them expressed satisfaction with the salaries they received as teachers in India.

Both Shammi and Leena were paid according to standardized pay scales determined by the (state) provincial government based on education and training levels and years of experience. This gave them a sense of being treated fairly. Shammi was at the highest level in her range because of her experience and supervisory role. She recognized that the amount of salary she received could not be compared with what she received as an ECE because “...you can't compare rupees and dollars because they're two different lifestyles.” Leena had a B.Ed. degree and also felt she received a fair salary based on her qualifications. She contrasted this with her experience in Ontario, where she had invested time and effort in studying to take an exam to get registered as an ECE but the registration did not make any difference to her income. She went on to say, “...there is no difference between my registering and a nurse being registered to work” but her registration did not lead to a raise or additional benefits.

The fact that their salaries were calculated on the basis of hours of work was something both of them found demeaning. They compared that to working in factories as unskilled 
labourers or in the retail industry, which does not require any or minimal professional training. Shammi referred to herself as a "professional labourer" because in her view professionals are not paid according to the number of hours they work but on a monthly basis, according to the nature and quality of their work. As teachers, both Shammi and Leena qualified for pension funds, to which their schools also contributed. In Canada, both the participants contributed to their pension based on their pay but their employers did not contribute to this fund.

Both Shammi and Leena said the number of hours they worked as ECEs were much longer than they had worked as teachers. Shammi's working hours in India were from 8:30a.m. till 2:30p.m. Monday through Saturday. The children she taught would start leaving at 12:40 and she monitored this process until 1pm. From 1pm-1:30p.m. was break time only for teachers of young children such as herself. From 1:30-2:30 she prepared her class for next day, doing up bulletin boards, planning activities for the next day, laying out the materials and writing progress reports etc. By the time some or all of those tasks finished it was time for her to go home. Leena's day was very similar in India. She taught from 7:30a.m. - 2:30p.m. Monday to Friday. Each morning they would have a morning assembly where the entire school (all the grades up to 12) would get together and sing the national anthem and listen to any announcements for all the students such as holidays or events. After the assembly all the children and teachers would disperse to their own classrooms. She was allocated 45 minutes for planning and 30 minutes as lunch break each day. Over here their day begins at 7 or 8 depending on the shift. One is from $7 \mathrm{am}-4 \mathrm{pm}$ and the other is from 9am-6pm where they get 60 minutes of lunch break and no other break in the middle. They also get 60 minutes of planning once a week to plan for the next week. Both participants said that they were able to spend more time at home when they were living in India. 
The amount of time they had as holidays and as paid vacation in India was also quite different from what they received here. For Shammi, this included 10 days for Diwali, two months of summer vacation, two weeks for Christmas holidays and most Indian festivals and national holidays (Independence Day, Republic day, Gandhi’s birthday, etc.). In addition, she also had 10 casual leave days and 6 medical leave days that were all paid. Leena also confirmed that she benefitted from all of these holidays.

Currently at the daycare where they work, after completing their probation period they receive 10 paid vacation days for the full year and 3 'personal days.' They can also have 8 sick days along with 10 days for emergency leave, both of which are unpaid. In order to use the emergency days they have to provide documentation. Along with these days they get all the 9 long weekends off in Ontario. The daycare is open for limited hours during Christmas and New Year. They can also accumulate 'in lieu' time, which is accumulated by attending staff meetings or special events, and can be used towards one day off. Both of them said they have to plan months in advance to get a day off, and sometimes this is still not be possible if there is a shortage of supply teachers, which is an ongoing problem.

When working as teachers in India, both of them also received many benefits, for themselves and for their families. Shammi did not have to pay school fees for her children, who attended the same school and different school as they got older. Even though she had to pay for their books and uniforms, she received a discount on those items because of her status as a teacher. She also received medical benefits including a discount at certain hospitals. Similarly, Leena's children's education was free at the school where other parents would normally pay a significant amount of fee. In addition, Leena had paid accommodation. In comparison, in Canada they receive some medical benefits for themselves, but not for any member of their family. 
Opportunities for professional development were available to both Shammi and Leena in both places. In India Shammi attended workshops and seminars organized by her school for professional development. Sometimes she attended in-house training and organized workshops for her colleagues. Leena also attended workshops organized by her school. Almost all the workshops organized by the schools in India were free of cost.

In Canada, both the participants continue to attend workshops. However, a key difference is that taking professional development courses is tied to payment of increments and closely monitored by the daycare administrators. The management keeps a track of who is going to which workshop to ensure that both teachers from the same classroom are not in the same workshop. If they choose to attend any other workshops that costs money they are reimbursed after they have submitted their proof of payment and attendance. Appreciation, community-building and respect

Shammi and Leena talked extensively about the appreciation they received from their employers, and their sense of self-efficacy and the respect they received in their roles as teachers in Indian schools. On September 5th every year Shammi’s school celebrated teacher’s day. Lunch was provided by the school and then they had dinner with their spouses at a restaurant, paid for by the school. Before the school broke off for summer vacation, the school provided lunch in a restaurant for all of the staff. Similarly before Christmas vacation she attended a picnic organized by the school.

Sometime earlier, the previous managers of the daycare where they now worked had given them tokens and a sense of some appreciation experienced from their employer. Every now and then they would let the staff know that they were appreciated by doing little things such as giving them an extra 10 minutes in their break, a cup of hot chocolate, giving them 
windcheaters with the daycare logo, etc. One Christmas, all employees were given $\$ 100$ gift card. But many of these offerings had now stopped. Last Christmas each member of the staff was given a turkey. Shammi, was a vegetarian. She thought it demonstrated a lack of cultural sensitivity to give her a gift she could not use.

Organizing and participating in celebrations and special events also enhanced the teachers' sense of being a member of the school community. Shammi's school in India organized an Annual Fair where the children as well as the staff and their families enjoyed rides, games, and food stalls etc. The school also organized an annual sports day where the children participated in relay races, in marching bands and competed in different sports. In addition, Shammi used to arrange inter-class competitions in English and Hindi calligraphy, English and Hindi recitals, and English and Hindi storytelling and drawing and dance competitions for her entire Montessori group. She also organized day picnics or day tours off school property to places such as mosques, temples, churches and historical places. She also took the kids out of the city for excursions and some of them were overnight trips as well. Similarly, Leena organized educational day trips and accompanied the children to places of interest outside the school. She also participated in other trips organized by her school.

When Shammi and Leena worked with the kindergarten or preschool children respectively at their current place of work, they used to go to on educational trips away from the daycare. However, now that both are working with older toddlers/young preschoolers it is difficult for them to plan any trips away from the daycare.

The one thing that both teachers spoke about with a lot of passion was their feeling that they were not respected in their professional roles. When asked to identify some differences between the work they did in India and the work they did here, both participants stated lack of 
respect as being one of the biggest differences. They said that the work of ECEs is not seen as a profession in Canada. According to Leena, "teaching is a respectable job and it's seen as a profession...childcare is seen as babysitting.” Both participants stated that in India they were not just respected by the students but by parents and society overall, which they found missing here in their current professional roles. Most parents at the daycare just dropped their children and rushed off to their jobs, and picked up their children, again in a rush. They did not take the time to engage in a respectful conversation with them. Managers of the daycare also did not treat them with the respect they deserved. Shammi illustrated this by her reaction to the 'uniform' she is expected to wear once a week. She despises the fact that each employee and the child at the daycare are given a coloured t-shirt that they must wear on a specific day. For example, on Thursday they wear a purple t-shirt. While putting on her t-shirt over her own clothes, Shammi muttered under her breath that wearing the t-shirt makes her feel as though she is a slave.

Shammi and Leena believed that the most important reason for their lack of respect was the low salaries and poor working conditions. They thought that they made an important contribution to society by caring for young children, but this contribution was not recognized by society. Leena said that they were treated no better than factory workers while their work involved taking care of the most precious asset of this society.

\section{Discussion}

This study was conducted to find out what changes, if any, take place in the professional identities and practices of immigrant teachers from India who now work as ECEs. As the above data show, both participants feel that their identity as teachers, as skilled and respected professionals, was now essentially reduced to that of 'babysitters,' a term that is associated with 
unskilled, low-paid work mostly done by young high school children trying to make quick money. Through analysis of the interviews it is evident that becoming an ECE was not their preferred way to enter the labour market in Canada. They wanted to be certified teachers as they had been in India. Thus, becoming an ECE was rather a survival job for them that became a career by default. They attribute this change to the difference in the nature of their work as well as working conditions, and a lack of appreciation, community, and respect.

These findings need to be located generally within the context of immigrants' experiences in the Canadian labour market, as well as specifically within the context of teachers' work in India and ECEs' work in Canada. Shammi and Leena’s credentials as teachers, and work experience in India were not recognized by Canadian authorities, which in and of itself signals devaluation of their prior knowledge and experiences. This is no different from what many other immigrants experience in many other professions (Bauder, 2003). Teachers working in Canadian schools enjoy higher salaries and greater respect for their professional expertise than ECEs. Even within Canada, if someone who has the credentials and experience to work as a teacher, she would consider it a downgrading of her professional identity if she had to work as an ECE. Shammi and Leena had no choice in this matter. Like the immigrant teachers Maitra (2011) had studied, they were now working in a lower level profession. Their training and prior experience led them to think of themselves as teachers, not ECEs. However, they could not enter the teaching profession in Canada and instead chose to take up a profession that had lower level requirements and lower level compensation, and thus a lower level professional status (Tozer, 2012; de Leon-Carillo, 2007).

The fact that both teachers had come from India, and from schools that were regulated by the government added another layer to their perceptions of being diminished in their professional 
status. For women, teaching is regarded as a well-respected profession in India. The traditional notions of guru-shishya underscore the importance of teachers in Indian society. In addition, teachers play a significant role in helping students pass examinations at every level, which are critical for their subsequent academic success. Therefore parents as well as school administrators highly value teachers who facilitate the academic success of children in their charge (Gupta, 2006). When Shammi and Leena's role as facilitators of academic learning was diminished in the setting in which they now worked, they felt that their professional identity itself was undermined. Furthermore, they were expected to just let the children learn through play, which made them feel like passive observers, and not dispensers of worthwhile knowledge and skills. In addition, their work included the physical care of the children and their classroom, which are considered menial tasks in India, usually performed by low-caste, low-paid employees in homes, offices, and factories. For them, this was a huge jump down the ladder of professional status, identity and self-worth.

In their roles as teachers in India, Shammi and Leena exercised power and control by disciplining the children, teaching them valuable knowledge and skills, formally assessing their progress and informing parents about it. Here, they seemed to lose that sense of self-efficacy. They distinguished 'play' from 'learning' and thought that because they were not engaging children in learning, they were not doing worthwhile work.

Both teachers had worked in schools where salaries and benefits were regulated by the government. This gave them the sense that they were being treated well, because everyone was else was also subject to the same standard rules and regulation. In Canada, their registration as a RECE made no difference to their salaries and benefits, which made them think they were entirely dependent on their private sector employer for these. Changes in the management of the 
centre where they worked led to further reduction in tokens of appreciation. As they seemed to have no options but to continue to work at the same centre, their helplessness was underscored. Like many other women immigrants in Canada, Shammi and Leena were stuck in jobs that reduced their professional self-worth (see Shan, 2009 and Iredale, 2004).

In their practice the two teachers seemed to have adapted to their current workplace. They followed the routines that are common in most childcare centres, including reading to the children during 'circle time,' organizing their snacks and lunch, arranging their cots for nap-time etc. They had also shifted their focus to teaching the children social and emotional skills rather than reading and writing etc. They seemed to have made this shift because they believed this is what their management wanted them to do. As Wagner (2010) has pointed out, the environment in which they worked, and their relationship with significant people in their environment (in this case their managers) shaped their everyday practices. Beijaard et al., (2004) tell us that many educational changes may conflict with teachers' desires, and experiences as 'good.' Shammi and Leena had clearly adapted to their new environment, including in their use of technology to record children's progress.

However, their own beliefs about what and how they should teach children had not changed much. Their dominant teacher identity lurked in their daily practices as ECEs, emerging in their tone of voice, or in their insistence of having the children sit in rows, or raise their hands to be granted permission to speak. Lortie’s (1965) and Elbaz’ work (1981) suggests that Shammi and Leena must recall and confront their own images of what teachers' work looks like, based on their experiences as students and then as teachers in India. They should then critically examine their current environment and assess whether those images should be used to guide their practice as ECEs. This kind of deliberate and thoughtful analysis could help them make conceptual shifts, 
rather than simply go along doing what they think they should do, even if they do not believe in it.

Nias (1989) and Day et al (2006) have written about the conflict between primary teachers’ impulse to ‘care and nurture’ and to ‘control’ and teach an externally imposed curriculum in response to institutional requirements. In this case it was the opposite. The institutional requirement was to care and nurture, while the teachers' own desire was to control and teach a formal curriculum. Their own prior experiences as classroom teachers, as well as their sense of being respected, well-paid professionals, who exercised power and control, made them value their teacher self more than their ECE self.

More importantly, in the social milieu in both India and in Canada, the professional status of the teacher is clearly higher than that of the ECE. Even if Shammi and Leena were inclined to play the caring and nurturing role in their practice, they would continue to think that it was less valuable work than that of a teacher.

\section{Conclusion}

This study showed that two former teachers from India, now working as ECEs in Canada, felt a sense of loss in their professional identities. They believed the nature of their current work was less valuable, which was also reflected in their relatively low compensation, and in the reduction in appreciation, community, and respect they had enjoyed as teachers. Their practices had changed according to the setting in which they worked, primarily because they believed they had to do what their managers wanted them to do, but their beliefs about their work had not changed. Some of the implications of this study are as follows: 
Soon after immigration most women’s professional development result in stagnation. In the early days of their settlement period, most of them are focused on supporting their husbands and children to settle in the new environment. As dependants of male principal applicants their own career trajectories receive less attention. They have fewer opportunities for career counselling or for further education or bridging programs. Thus, their employment options become further reduced. Well-educated immigrant women could make an important contribution to the profession of Early Childhood Education. In a country where immigration is so high, particularly in the large cities, immigrant women working as ECEs could help to ensure that Canadian children learn to reject cultural hierarchies in favour of genuine multiculturalism, starting at a young age. But to do this, institutional leaders at all levels would have to see such women not from the lens of deficits but as an asset in an increasingly diverse society. To make them feel they are valued contributors to the education of young children, they would have to be paid at the same rate as other teachers, in a transparent and equitable manner. They would also have to be treated with as much respect as other professionals, in terms of autonomy and participation in decision-making. If change in their practices is desired, then their beliefs would have to be engaged through dialogue and debate, rather than through command and surveillance. It is a truism to say that when people are treated as professionals in the workplace, they take initiative and responsibility and give their best to the work they do.

In order to make this change, their employers would also have to be engaged in a dialogue to shift their perspectives on immigrant women working as ECEs in their centres. They could be helped to discover the strengths of their diverse cultural backgrounds and their experiences as teachers, both of which could enhance the learning environment provided to the 
children in the centres. This may entail helping the employers confront their own prejudices and beliefs in hierarchies of cultures.

Structural changes are central to fair and equitable compensation for the work that ECEs do, but these changes are likely to take a long time to implement. Meanwhile, small tokens of appreciation can be offered right away, at minimal cost. The fact that participants in this study mentioned these tokens in such details means that they appreciated these tokens. Their employers could show their appreciation of the ECEs work through such tokens right away.

Pre-service and in-service training of ECEs usually emphasizes practical training, along with some theoretical knowledge. It hardly ever includes the engagement of trainees’ prior values and beliefs about what young children should learn, why, and how. As this study shows, they may replicate the tasks and activities they see in their places of work but they do not necessarily believe in them. If ECEs who are formally trained and registered by the College still differentiate between 'learning' and 'play' then they have clearly misinterpreted the notion of learning through play. A critical examination of what is considered worthwhile learning in different contexts, and how children in different societies are helped to learn that which is considered worthwhile, needs to be a part of the curriculum for ECEs in training.

AECEO is the primary institution which regulates the profession of Early Childhood Educators and offers opportunities to ECEs to enhance their qualifications and training. For example, the AECEO has a new project called 'Professional Pay for Professional Work.' However, Shammi and Leena were either unaware of this opportunity or unable to use it. Nevertheless, they or other teachers like them could potentially use the services of AECEO to enhance their professional experience and eventually their professional status. 
Limitations of this study point to future directions for research. This study was based on a very small sample of two teachers. Nevertheless, the ideas they generated could be tested with larger samples so some generalizations can be made. For example questions such as the following may be explored by other researchers:

- Do former teachers from countries other than India think the same way about their work as ECEs as these teachers did?

- Do ECEs employed in the public sector / school boards have the same perceptions as these teachers did?

- Are there differences in professional identities of immigrant women when working in for-profit, non-profit daycares and lab schools?

- What kind of pre-service and / or in-service training would help to shift former teachers' beliefs about what and how they should teach young children?

- What differences, if any, would ECEs' compensation packages make to their sense of professional self-worth? 


\section{Appendix 1}

\begin{tabular}{|c|c|}
\hline Governance Model Group & $\begin{array}{l}\text { Types of Governance Models Included in } \\
\text { Group }\end{array}$ \\
\hline 1. Commercial/Private organization & $\begin{array}{ll}\text { - } & \text { Sole proprietor } \\
\text { - } & \text { Corporation } \\
\text { - } & \text { Partnership } \\
\text { - } & \text { Franchise } \\
\text { - } & \text { Co-op (for-profit) }\end{array}$ \\
\hline 2. Non-profit Board & $\begin{array}{l}\text { - } \quad \text { Parent board member operated } \\
\text { - } \quad \text { Community board member operated } \\
\text { - }\end{array}$ \\
\hline 3. Aboriginal organization & $\begin{array}{ll}\text { - } & \text { First Nations Band/Tribal Council } \\
\text { operated } & \\
\text { - } & \text { Aboriginal Human Resources } \\
& \text { Development Agreement (AHRDA) }\end{array}$ \\
\hline 4. Community organization & $\begin{array}{ll}\text { - } & \text { Community organization (e.g. } \\
\text { YMCA/YWCA, etc.) } \\
\text { - } \quad \text { Religious institution }\end{array}$ \\
\hline 5. Worksite/private company & - Worksite/private company operated \\
\hline $\begin{array}{l}\text { 6. Educational institution/hospital } \\
\text { organization }\end{array}$ & $\begin{array}{ll}\text { - } & \text { University or college } \\
\text { - } & \text { School board } \\
\text { - } & \text { Hospital }\end{array}$ \\
\hline 7. Government organization & $\begin{array}{ll}\text { - } & \text { Municipal/local government } \\
\text { - } & \text { Provincial/territorial government }\end{array}$ \\
\hline
\end{tabular}

Source: Employer Models in Canada's Early Childhood Education and Care (ECEC) Sector: Supporting Employers in Canada’s ECEC Sector. (2008) By: Costigliola, Bozica 


\section{Appendix 2}

Interview 1 questions:

1) What was your work in India? Please describe (school, work, daily routine, number of years, professional status, satisfaction with salary and other rewards)

2) Why and when did you migrate?

3) What kind of job did you look for? How? How did you prepare for those jobs?

4) What made you choose ECE as a field?

5) How would you compare your work environment as a teacher in India and as an ECE here?

6) How would you compare your role in the classroom in India and here?

7) How would you compare your level of satisfaction with your work in India and here in terms of salary, status and other rewards?

8) Anything else I’ve left out?

9) What advice might you offer to others in the similar situation? 


\section{Appendix 3}

Interview 2 questions - After the observation

1. I noticed that you first did (X, Y, Z routine) then... what was your reasoning for ...

2. I noticed that (interactional style: i.e. body language, tone, eye-contact, vocabulary etc.) when you were talking to .... Tell me your reasoning for ....

3. How is the role you play here different from that in your previous job in India?

4. How did you learn to make this transition? What/who helped? How?

5. How do you feel about your work here versus your work in India? 
Appendix 4

Participants name:

Date:

Observer:

Place:

Time period:

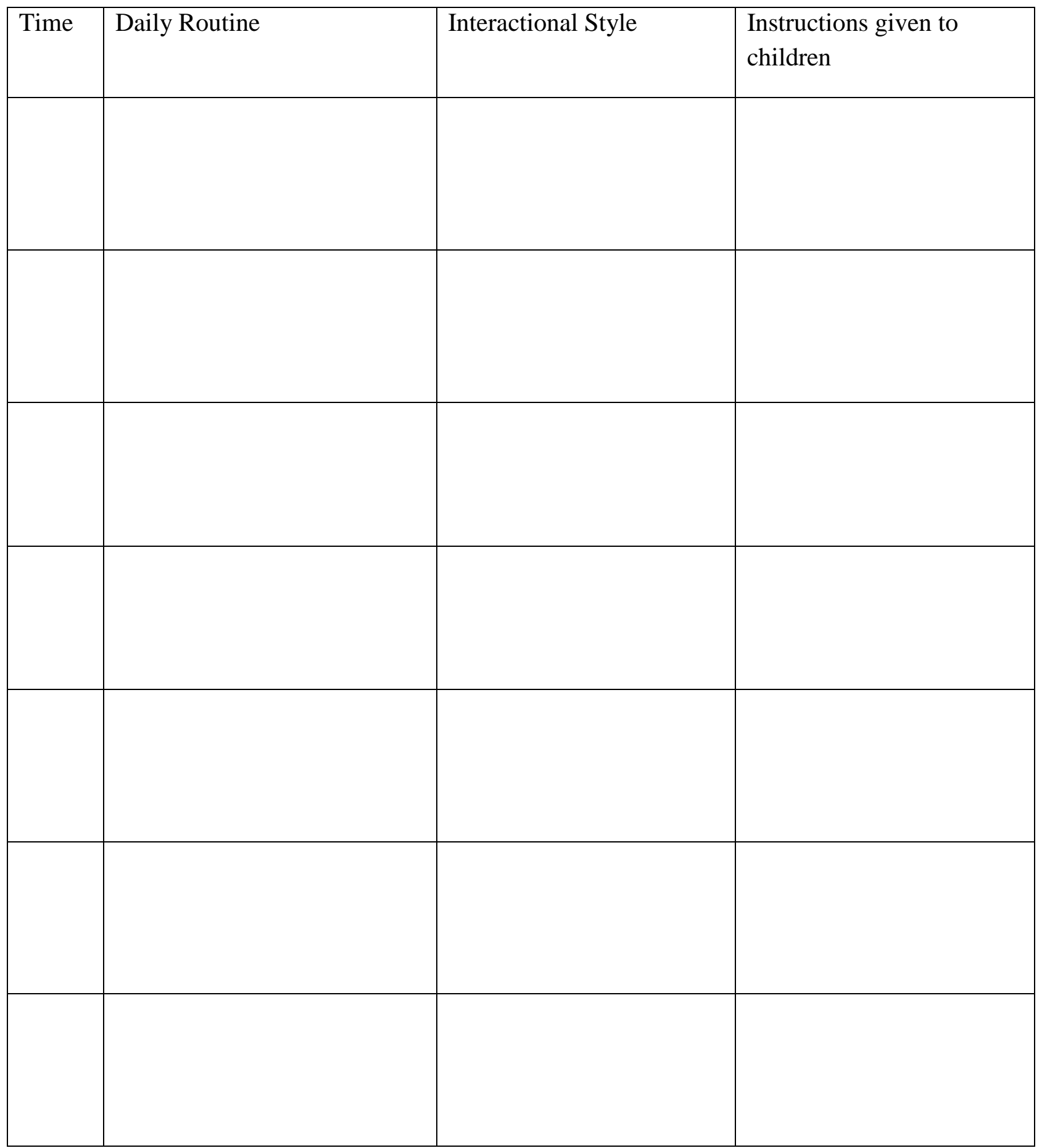




\section{Appendix 5}

(Ryerson letterhead and copy for potential participant)

How does the professional identity and practice of elementary teachers from India change when they work as Early Childhood Educators in Ontario?

Information Sheet and Consent Form for participants

You are being asked to participate in a research study. Before you agree to be a participant, please read the following information, or ask the researcher to read it to you, and ask as many questions as you want to be sure you understand everything about this project.

Investigators:PreetiAlwani is conducting research in partial fulfillment of my graduate degree in Immigration and Settlement Studies Department. Being supervised by Dr. Mehrunnisa Ali Telephone Number (416) 979-5000 x 6330; maali@ryerson.ca

Purpose Of Study:This research will focus on the shift in professional identity and practice of elementary teachers from India as Early Childhood Educators in Ontario. This research will shed light on how they transition into a different professional identity and practice.

\section{Procedure:}

You will be required to complete the following:

1) Personal interviews. For these interviews you will indicate yourchoice of location based on your comfort level (ie: room in a public library or Ryerson library etc.). One interview will be conducted before the observation in the classroom. The second interview will be conducted after the observation. The interviews will last approximately 45 minutes to 1 hour each time. The interviews maybe audio recorded.

2) Observation in the professional environment. The observation is to see what kind of programming is planned and how it is implemented. Specifically looking at: (1) daily routines (2) interactional style (eye contact, voice tone, etc.) (3) instructions given to the children (choice of words, etc.) The observation will last 3 consecutive days for approximately 8 hours a day. Although there are children involved in the setting, they are not the focus of the study. Hence, at no point during the observation will children be observed.

Risks or Discomforts:The risks involved in this study are minimal. You will be aware of the focus of the research and the type of atmosphere that might be created. Hence, if you feel uncomfortable about being observed or discussing any experiences the researcher will stop probing for more information. Additionally, one of the investigators is affiliated with a settlement agency where they offer counseling services in various Indian languages. If you feel the need, you could be referred to the agency where they are trained to support immigrants. 
Benefits of the Study:You may not gain any direct benefit from participating in this study. The purpose of this study is to examine how the accreditation process and settlement experience of professional immigrants affects their professional identity. The emphasis on understanding the former teacher or current educator's identitythrough participation in this research opens possibilitiesfor future research on the self-knowledge of teachers and creates an area where identity transformation of educated professionals can be explored.

Confidentiality: All data gathered through all the methods will be kept confidential on a password protected computer belonging to the researcher. All the data that is in hard copy will be kept in a locked drawer with the researcher. Dr. Mehrunnisa Ali will also have access to the data. The data will be stored until October 2014 after which all data gathered will be destroyed. The results of the study may be published or presented at professionalmeetings, but the participants' identity will not be revealed. The identities will remain confidential and names will not be used in any reports or publications resulting from the research

Incentives to Participate: Participants are not offered any incentives to participate in this study.

Costs and/or Compensation for Participation: There will be no costs for you to participate in this study, and you will not be compensated for participating in this study

Voluntary Nature of Participation: Participation in this study is voluntary. Your choice of whether or not to participate will not influence your future relations with Ryerson University or your place of employment. If you decide to participate, you are free to withdraw your consent and to stop your participation at any time without penalty or loss of benefits to which you are allowed. At any particular point in the study, you may refuse to answer any particular question or stop participation altogether.

Questions about the Study: If you have any questions about the research now, please ask. If you have questions later about the research, you may contact.

PreetiAlwani or Mehrunnisa Ali

palwani@ryerson.ca

Telephone Number (416) 979-5000 x 6330

maali@ryerson.ca

If you have questions regarding your rights as a human subject and participant in this study, you may contact the Ryerson University Research Ethics Board for information.

Research Ethics Board

c/o Office of the Vice President, Research and Innovation

RyersonUniversity

350 Victoria Street 


\section{Agreement:}

Your signature below indicates that you have read the information in this agreement and have had a chance to ask any questions you have about the study. Your signature also indicates that you agree to be in the study and have been told that you can change your mind and withdraw your consent to participate at any time. You have been given a copy of this agreement.

You have been told that by signing this consent agreement you are not giving up any of your legal rights.

Name of Participant (please print)

Signature of Participant

Date

Do you agree to be observed in your classroom for maximum 8 hours for academic and professional purposes only.

Yes No

Do you agree to be audio-recorded, understanding that you ask the recorder to be shut at any point, and that the tape will be destroyed one year after the completion of the project.

Yes No

Signature of Participant

Date

Signature of Investigator

Date 


\section{References}

Alboim, Naomi, and Elizabeth McIsaac. (2007). Making the Connections: Ottawa's role in Immigrant Employment. IRPP. http://www.irpp.org/fasttrak/index.htm

Archer, K. \&Berdahl, L. (2011). Explorations: Conducting Empirical Research in Canadian Political Science, 2nd Edition. Toronto, ON: Oxford University Press

Association of Early Childhood Educators in Ontario (AECEO) $<$ http://www.aeceo.ca/public_policy)

Baptiste, L. J. (2013). Stories of Racialized Internationally Trained Post-Secondary Educators Re-entering their Professions (Doctoral dissertation, University of Toronto).

Bartesaghi, M., \& Castor, T. R. (2008). Social construction in communication: Revisiting the conversation. Communication Yearbook (Vol. 32, pp. 5-30). Thousand Oaks, CA: Sage..

Bauder H. (2003). “Brain abuse”, or the devaluation of immigrant labour in Canada' Antipode 35(4), 699-717

Beijaard, D., Meijer, P. C., \&Verloop, N. (2004). Reconsidering research on teachers’ professional identity. Teaching and Teacher Education, 20(2), 107-128.

Berg, B. (2007). Qualitative research methods for the social sciences (3rd ed., p. 384). Boston: Pearson.

Beynon, J., Ilieva, R. Dichupa, M. (2004). Re-credentialling experiences of immigrant teachers: Negotiating institutional structures, professional identities and pedagogy. Teachers and Teaching: Theory and Practice, 10 (4), 429-444.

Bhattacharya, R., Gupta, S., Jewitt, C., Newfield, D., Reed, Y., \& Stein, P. (2007). The Policy-Practice nexus in english classrooms in delhi, johannesburg, and london: Teachers and the textual cycle. TESOL Quarterly, 41(3, Language Policies and TESOL: Perspectives from Practice), 465-487.

Browne, I. \&Misra, J. (2003). The Intersection of Gender and Race in the Labor Market. Annual Review of Sociology, 29, 487-513.

Burnard, P., Gill, P., Stewart, K., Treasure, E., \& Chadwick, B. (2008). Analysing and presenting qualitative data. British dental journal, 204(8), 429-432. 
Charmaz, K., \&Belgrave, L. (2002). Qualitative interviewing and grounded theory analysis. The SAGE handbook of interview research: The complexity of the craft, 2.

Chaudhury, Nazmul, Jeffrey Hammer, Michael Kremer, KarthikMuralidharan, and F Halsey Rogers. 2006. "Missing in Action: Teacher and Health Worker Absence in Developing Countries." Journal of Economic Perspectives, 20:1, pp. 91-116.

Chen, C., Smith, P. \& Mustard, C. (2010). The prevalence of over-qualification and itsassociation with health status among occupationally active new immigrants to Canada.Ethnicity \& Health, 15, 601-619.

Cho, Christine, (2010). Qualifying as Teacher: Immigrant Teacher Candidates’ CounterStories. CanadianJournal of Educational Administration and Policy 100: 1-22

Chui, T. (2011). “Immigrant Women”. Retrieved from http://www.statcan.gc.ca/pub/89503-x/2010001/article/11528-eng.htm\#a1.

Citizenship and Immigration Canada. (2011). Annual Report to Parliament on Immigration. <http://www.cic.gc.ca/english/resources/publications/annual-report2011/section5.asp >

Coldron, J., \& Smith, R. (1999). Active location in teachers' construction of their professional identities. Journal of Curriculum Studies, 31(6), 711-726.

College of Early Childhood Educators (CECE) $<$ http://www.college-ece.ca/en/Public/Pages/About-ECEs.aspx>

Corbin, J. M., \& Strauss, A. (1990). Grounded theory research: Procedures, canons, and evaluative criteria. Qualitative sociology, 13(1), 3-21.

Cornwell, Erin York; Cornwell, Access to Expertise as a Form of Social Capital: An Examination of Race and Class - Based Disparities in Network Ties to Experts. Benjamin.Sociological Perspectives 51.4 (Jan 2008): 853-876.

Crenshaw, Kimberlé (1993) ‘Beyond Racism and Misogyny’, in M. Matsuda, C. Lawrence and K. Crenshaw (eds) Words that Wound. Boulder, CO: Westview Press.

Creswell, J. (2009). Research Design: Qualitative, Quantitative, and Mixed Methods Approaches (3rd ed., p. 260). Sage. 
Day, C., Alison Kington, Gordon Stobart, \& Sammons, P. (2006). The personal and professional selves of teachers: Stable and unstable identities. British Educational Research Journal, 32(4), 601-616.

Day Nurseries Act. (2013). < http://www.e-laws.gov.on.ca/html/regs/english/elaws_regs_900262_e.htm\#s7>

de Leon-Carillo, C. M. (2007). Prospective teacher's pre-and post- practicum beliefs on teaching. KEDI Journal of Educational Policy, 4(1), 25-40.

Dean, J.A., \& Wilson, K. (2009). 'Education? It is irrelevant to my job now. It makes me very depressed...': Exploring the health impacts of under/unemployment among highly skilled recent immigrants in Canada. Ethnicity \& Health, 14, 185-204.

Dean, J. (2011). The economic integration of Canadian immigrants.

Doherty, G., Friendly, M., \& Forer, B. (2002). Child care by default or design? An exploration of differences. Occasional paper, 18, 0-75.

Erikson, E. H. (1968). Identity: Youth and Crisis. New York: Norton.

Feiman-Nemser, S. (1983). Learning to teach. In L. Shulman and G. Sykes (Eds.), Handbook of teaching and policy (pp. 150-170). New York: Longman.

Ferrer, A., \& Riddell, W. C. (2008). Education, credentials, and immigrant earnings. Canadian Journal of Economics, 41(1), 186-186.

Ferrer, A. M., Picot, G., \& Riddell, W. C. (2012). New Directions in Immigration Policy: Canadaâ€ $€^{\mathrm{TM}}$ s Evolving Approach to Immigration Selection (No. clsrn_admin- 201234). UBC Department of Economics.

Fontana, A., \& Frey, J. H. (2000). The interview: from structured questions to negotiated text. In N. K. Denzin\&Y. S. Lincoln (Eds.), Handbook of qualitative research （2nd ed.) (pp. 645-672). Thousand Oaks, CA: Sage

Foucault, M. (1981). The order of discourse. In R. Young (Ed.), Untying the text: A poststructuralist reader (pp. 48-78). London, UK: Routledge and Kegan.

Fuller, S., \& Martin, T. F. (2012). Predicting immigrant employment sequences in the first years of settlement. International Migration Review, 46(1), 138-190.

Gananthan, G. (2011). Implications of Full-Day Kindergarten in Program Policy on Early Childhood Pedagogy and Practice. International Journal of Child Care and Education Policy, 5 (2), 31-43. 
Goldman, Gustave \&Sweetman, Authur\&Warman, Casey (2009) „The Economic Return on New Immigrants ${ }^{\text {ee }}$ Human Capital: The Impact of Occupational Matching ${ }^{\text {ee }}$ Canadian Labour Market and Skills Researcher Network, no. 21

Gergen, K. (1991). The saturated self: Dilemmas of identity in contemporary life. Basic books.

Gestwicki, C. and Bertrand, J. 2003. The essentials of early childhood education, (2nd), Toronto: Nelson Thomson

Ginsburg, M. B., Chaturvedi, V., Agrawal, M., \& Nora, A. (1988). Teachers and the ideology of professionalism in india and england: A comparison of cases in Colonial/Peripheral and Metropolitan/Central societies. Comparative Education Review, 32(4), 465-477.

Girard, E. R., \&Bauder, H. (2007). Assimilation and exclusion of foreign trained engineers in Canada: Inside a professional regulatory organization. Antipode,39(1), 35-53.

Government of India, Ministry of Human Resource Development (2007) $<$ http://www.educationforallinindia.com/SES2004-05.pdf > $<$ http://vertexcareer.com/annual-report-2007-08-on-education>

Gulati, N. Becoming a teacher: Voices from graduates of a professional teacher education programme1. Voices of Teachers and Teacher Educators,(2)2, 23-34.

Gupta, A. (2006). Early childhood education, postcolonial theory, and teaching practices in India: Balancing Vygotsky and the Veda. Macmillan.

Gupta, A. (2008). Tracing global-local transitions within early childhood curriculum and practice in india. Research in Comparative and International Education, 3(3), $\quad 266-$ 280.

Hirji, S., \&Beynon, J. (2000). Teachers of Punjabi-Sikh ancestry: Their perceptions of their roles in theBritish Columbia education system. The Alberta Journal of Educational Research, XLVI, 250-266

Hall, P. V., \&Sadouzai, T. (2010). The value of "experience" and the labour market entry of new immigrants to Canada. Canadian Public Policy.Analyse De Politiques, 36(2), 181.

Houle, R. \&Yssaad, L. (2010). Recognition of newcomers' foreign credentials and work experience. Perspectives in Statistics Canada Catalogue, 75, 18-33.

identity. (n.d.). Collins English Dictionary - Complete \& Unabridged 10th Edition.

Retrieved March 01, 2014, from Dictionary.com website:http://dictionary.reference.com/browse/identity 
Iredale, R. 2004. 'Gender, Immigration Policies and Accreditation: Valuing the Skills of Professional Women Migrants’, Geoforum35 (6).

Jenkins, R. (2002). Pierre Bourdieu. London: Routledge.

Johnson, R. B., \& Onwuegbuzie, A. J. (2004). Mixed methods research: A research paradigm whose time has come. Educational researcher, 33(7), 14-26.

Johnson, Keith (2008, December). Pan-Canadian Quality Standards in International Credential Evaluation. Human Resources and Skills Development Canada (HRSDC)

Kale, P. (1970). The guru and the professional: The dilemma of the secondary school teacher in poona, india. Comparative Education Review, , 371-376.

Kelley, N. and M. Trebilcock. (2000). The Making of the Mosaic: A History of CanadianImmigration Policy. Toronto: University of Toronto Press.

Kingdon, Geeta Gandhi (1996), ‘Student Achievement and Teacher Pay’, Discussion Paper 76,Development Economics Research Programme, STICERD, London School of Economics.

Kostogriz, A., \& Peeler, E. (2007). Professional identity and pedagogical space: Negotiating difference in teacher workplaces. Teaching education, 18(2), 107-122.

Krefting, L. (1991). Rigor in qualitative research: The assessment of trustworthiness. American journal of occupational therapy, 45(3), 214-222.

Maitra, S. (2011). Redefining “Enterprising Selves": Exploring the "Negotiation" of South Asian Immigrant Women Working as Home-based Enclave Entrepreneurs (Doctoral dissertation, University of Toronto).

Martinovic, D., \& Zhang, Z. (2012). Situating ICT in the teacher education program: Overcoming challenges, fulfilling expectations. Teaching and Teacher Education, 28(3), 461-469.

McIntyre, F. (2011). Transition to teaching 2010: Determined new teachers face increased wait times. Professionally Speaking, (March), 30-34.

Mead, G. H. (1934). Mind, Self and Society from the Standpoint of a Social Behaviorist. Chicago: University of Chicago Press.

Mir, G. A. T. (2013). What is my Pedagogy? (Doctoral dissertation, University of Toronto).

Moore, R. (2008). Capital. In M. Grenfell, Pierre Bourdieu Key Concepts (pp. 101-118). Stocksfield: Acumen. 
Myles, J., Cheng, L., \& Wang, H. (2006). Teaching in elementary school: Perceptions of foreign trained teacher candidates on their teaching practicum. Teaching and Teacher Education, 22, 233-245.

Nias, J., Southworth, G., \&Yeomans, R. (1989). Staff relationships in the primary school: A study of organizational cultures. Mansell.

Oloo, J. A. (2012). Immigrant teachers in Saskatchewan schools: A human resource perspective. KEDI Journal of Educational Policy, 9(2).

Ontario College of Teachers. 2011. <http://www.oct.ca/IET/?lang=en-CA>

Osgood, J. (2010). Reconstructing professionalism in ECEC: the case for the 'critically reflective emotional professional'. Early Years, 30(2), 119-133.

Osgood, J .(2004). Time to Get down to Business?: the responses of early years practitioners to entrepreneurial approaches to professionalism. Journal of Early Childhood Research, 2(1), 5-24.

Phillion, J.2003. Obstacles to accessing the teaching profession for immigrant women.. Multicultural Education, 11(1): 41-50

Pollock, K.(2006, June). Access to the teaching profession: Internationally educated teachers (IETs) experiences. Paper presented at the annual conference of the Research Network on Work and Lifelong Learning (WALL). $<$ http://www.wallnetwork.ca/resources/Pollock_Internationally_Trained_Teachers_WAL L2006.pdf $>$

Prentice, S. (2005). For-Profit Child Care: Past, Present and Future. Occasional Paper\# 21. Childcare Resource and Research Unit, University of Toronto, 455 Spadina Avenue, Room 305, Toronto ON M5S 2G8, Canada. Tel416:-978-6895.

Reitz, J.G. 2001. “Immigrant Skill Utilization in the Canadian Labour Market: Implications for Human Capital Research.” Journal of International Migration and Integration 2 (3): 347-78.

Rizk, N. J. (2003). Productive face-to-face interview. In Computer based learning in science: Conference proceedings (Vol. 1, pp. 927-986).

Ryan, J., Pollock, K., \&Antonelli, F. (2009). Teacher diversity in Canada: Leaky pipelines, bottlenecks, and glass ceilings. Canadian Journal of Education, 32(3), $\quad$ 591-617.

Sandelowski, M. (1986). The problem of rigor in quaJitative research. Advances in Nursing Science, 8, 27-37. 
Schellenberg, G. and Maheux, H., 2007. Immigrants' perspectives on their first four years in Canada: highlights from the three waves of the Longitudinal Survey of Immigrants to Canada. Canadian Social Trends, (Special Issue), 2_34.

Schmidt, C., \& Block, L. A. (2010). Without and within: The Implications of Employment and Ethnocultural Equity Policies for Internationally Educated Teachers. Canadian Journal of Educational Administration and Policy.

Schmidt, Clea (2010): Systemic Discrimination as a Barrier for Immigrant Teachers, Diaspora, Indigenous, and Minority Education, 4:4, 235-252

Schmidt, C., Young, J., \&Mandzuk, D. (in press). The integration of immigrant teachers in Manitoba, Canada: Critical issues and perspectives. Journal of International Migration and Integration.

Shan, H. (2009). Shaping the re-training and re-education experiences of immigrant women: The credential and certificate regime in Canada. The International Journal of Lifelong Education, 28(3), 353-369.

Shenton, A. K. (2004). Strategies for ensuring trustworthiness in qualitative research projects. Education for information, 22(2), 63-75.

Shpancer, N., Dunlap, B., Melick, K. M., Coxe, K., Kuntzman, D., Sayre, P. S., et al. $\quad$ (2008). Educators or babysitters? daycare caregivers reflect on their profession. Child Care in Practice, 14(4), 401-412.

Sumsion, J. (2007). Sustaining the employment of early childhood teachers in long day care: a case for robust hope, critical imagination and critical action. Asia-Pacific Journal of Teacher Education. 35, 311-327.

Teelucksingh, Cheryl, and Grace-Edward Galabuzzi. 2005. Working Precariously. The Impact of Race and Immigrant Status on Employment Opportunities and Outcomes in Canada. Toronto: Canadian Race Relations Foundation.

Tickle, L. (2000). Teacher induction: The way ahead. Buckingham: Open University Press.

Tozer, C. C. (2012). The Development of Team Relationships in Teacher and Early Childhood Educator (ECE) Integrated Staff Teaching Teams in Full-Day, Every Day Kindergarten (Doctoral dissertation, University of Toronto).

Türegün, A. (2011). CERIS-The ontario metropolis centre.

Urban, M., Vandenbroeck, M., Lazzari, A., Van Laere, K., \& Peeters, J. (2012). Competence Requirements in Early Childhood Education and Care. Final Report. Online Submission. 
Villagomeza, L. R. (2009). Shifting paradigms: The development of nursing identity in foreign-educated physicians retrained as nurses practicing in the United States (Doctoral dissertation, University of South Florida).

Wagner, B. D., \& French, L. (2010). Motivation, work satisfaction, and teacher change among early childhood teachers. Journal of Research in Childhood Education, $\quad$ 24(2), 152171.

Walsh, S. \& Brigham, S. (2007, December). Internationally educated teachers and teacher education programs in Canada: Current practices. Paper presented at the meeting of the Atlantic Metropolis Centre for Excellence, Halifax, NS.

Wang, H. 2008. Dancing with maple leaves: Labour market experience of immigrant women professionals (Master's thesis, University of Toronto, Ontario, Canada). Retrieved from http://hdl.handle.net/1807/16611z

Woodrow,C. (2007). W(H)Ither the early childhood teacher: tensions for early childhood professional identity between the policy landscape and the politics of teacher regulation. Contemporary Issues in Early Childhood, 8(3), 233-243. 